\title{
Trapped or spurred by the home region? The effects of potential social capital on involvement in foreign markets for goods and technology
}

\author{
Keld Laursen ${ }^{1,2}$, Francesca \\ Masciarelli ${ }^{3}$ and \\ Andrea Prencipe 4
}

${ }^{1}$ DRUID, Department of Innovation and Organizational Economics, Copenhagen Business School, Frederiksberg, Denmark;

${ }^{2}$ Center for Service Innovation, Department of Strategy and Management, Norwegian School of Economics and Business Administration, Bergen, Norway;

${ }^{3}$ Dipartimento di Economia Aziendale, University G. d'Annunzio, Pescara, Italy;

${ }^{4}$ Department of Business and Management, LUISS University, Rome, Italy

Correspondence:

K Laursen, DRUID, Department of Innovation and Organizational Economics, Copenhagen Business School, Kilevej 14A, Frederiksberg 2000, Denmark.

Tel: +4538152565 ;

Fax: + 4538152540 ;

email: kl.ino@cbs.dk

\begin{abstract}
Drawing on social capital theory and the international business literature, we argue that domestic geography, in terms of localized potential social capital, facilitates individual firms' awareness of business opportunities, including knowledge related to involvement in the foreign markets for goods and technology, thereby enhancing firms' involvement in those foreign markets. When potential social capital reaches a certain threshold, it may work to trap firms into operating only within their home regions, thus reducing involvement in foreign markets. We conjecture that firms' research and development investment moderates the relationship between potential social capital and degree of involvement in foreign markets, but given the very different properties of the two markets, with different signs for each market: a positive moderation effect for the markets for goods, and a negative effect for the markets for technology. We find empirical support for our arguments based on a representative sample of around 2000 Italian firms.
\end{abstract}

Journal of International Business Studies (2012) 43, 783-807.

doi: $10.1057 / j$ jbs.2012.27

Keywords: potential social capital; exports; technology sales; research and development

The online version of this article is available Open Access

\section{INTRODUCTION}

Globalization might be seen as questioning the effect of the local context on firm behavior, but, paradoxically, research shows that globalization increases rather than reduces the relevance of the local context for firms' strategic decisions. In the words of Michael Porter (2000: 32):

Globalization and the ease of transportation and communication have led to a surge of outsourcing in which companies have relocated many facilities to lowcost locations. However, these same forces have created the location paradox. Anything that can be efficiently sourced from a distance has essentially been nullified as a competitive advantage in advanced economies. Information and relationships that can be accessed and maintained through fax or email are available to anyone. Although global sourcing mitigates disadvantages, it does not create advantages ... Paradoxically, the most enduring competitive advantages in a global economy seem to be local. (original italics)
Received: 5 October 2010

Revised: 8 August 2012

Accepted: 24 August 2012

Online publication date: 15 November 2012 
Extant research has looked at how geographically proximate sources contribute to firms' competitive advantage. Porter $(1990,2000)$ proposes a framework to analyze how the co-location of related economic activities and actors (sophisticated and demanding local customers, and suppliers and related industries) within a particular geographic area can promote innovation and become the basis of competitive advantage in international markets. This framework constitutes an important contribution to our knowledge of the role of geographically localized factors in the international competitiveness of firms. However, the assumption that colocation implies that the organizations involved interact is a limitation; the model says little about the mechanisms that facilitate local knowledge and information flows in that context. There is also a large body of literature on international business that considers multinational corporation investment activities in foreign locations as aimed at tapping into the business knowledge of the foreign entities (Bartlett \& Ghoshal, 1989; Cantwell, 1989; Hedlund, 1986). This approach has been developed and refined, and is supported empirically (e.g., by, Almeida, 1996; Andersson, Forsgren, \& Holm, 2002; Flores \& Aguilera, 2007; Phene \& Almeida, 2008). Whereas the knowledge-related characteristics of foreign locations have been examined extensively, few studies have investigated how the opportunities for knowledge sourcing in the home location influence firms' involvement in foreign markets (for an exception, see Cantwell \& Janne, 1999).

This paper tries to fill some of these gaps in the literature. It explores the implications of home-region localized (potential) social capital understood as a critical contextual mechanism that facilitates access to knowledge and other resources for firms' international activities. We posit that the characteristics of the home region's social structure inform and define the opportunities for firms to access locally embedded resources through their effect on the circulation of knowledge. Accordingly, potential local social ties play an important role in facilitating firms' globalization efforts. In other words, the opportunities for knowledge flows in the domestic region influence the involvement of firms in foreign markets. A novelty of our paper is that it examines the relationship between potential social capital - a characteristic of the home region - and firms' involvement in foreign markets. We rely on standard measures of foreign market involvement, and distinguish between the internationalization of goods, measured by firms' export performance (e.g., Fernández \& Nieto, 2006), and the internationalization of technology, measured by firms' supply-side presence in the foreign markets for technology (e.g., Chen, 2005).

While our approach is similar to Porter's, it is novel in focusing on an important aspect of geography and its potential to "channel" resources such as information, knowledge, and complementary assets within a particular geographic space. We examine the level of social ties among individuals within a geographically contained area. Previous research shows that success in foreign markets requires that firms leverage the resources and knowledge of other organizations (Oviatt \& McDougall, 1994), which often is achieved through personal network ties (e.g., Coviello \& Munro, 1997; Ellis, 2000; Guler \& Guillén, 2010; Yli-Renko, Autio, \& Tontti, 2002; Zhou, Wu, \& Luo, 2007). Although work on the importance of social variables for firms' involvement in foreign markets has enhanced our understanding of the phenomenon, it does not link home geography, social variables, and involvement in foreign markets, either theoretically or empirically. Also, the studies referred to above highlight the positive effects of a favorable home location (Porter), or of social network ties, for international competitiveness. We include these positive effects in our model, but also explicitly model some important downsides of potential social capital for involvement in foreign markets.

Our view of social capital is based on Nahapiet and Ghoshal's (1998: 243) definition: "the sum of the actual and potential resources embedded within, available through, and defined from the network of relationships possessed by an individual or social unit". Our focus is on the important dimension of the strength of individuals' private social networks within geographical locations, and how firms can benefit from geographic location in areas characterized by individuals with an abundance of social ties. For the individual firm, a large number of social ties among individuals in a particular geographic location can be considered potential social capital: assuming that personal relationships and work relationships overlap, the managers and employees in firms located in regions characterized by high numbers of social ties can potentially draw on resources from within the same region. Social ties, facilitated by potential social capital, can transfer knowledge about business opportunities between firms and institutions, including knowledge about (local and foreign) markets, and facilitate access to the resources needed to commercialize products. 
We focus on the regional or sub-national level of analysis. We start from the premise that social ties are predominantly bound by geography (Putnam, Leonardi, \& Nanetti, 1993), and that since information and knowledge flows require frequent personal interaction, local social ties are important channels for knowledge exchange and knowledge flows (Almeida \& Kogut, 1999; Breschi \& Lissoni, 2009; Stuart \& Sorenson, 2003; Zucker, Darby, \& Brewer, 1998).

We argue that the social capital of the firm's home region enhances the degree of its involvement in foreign markets in terms of both tangible goods and intangible technologies. We also argue that, whereas the returns from potential social capital may be mostly positive for firm globalization, after a certain threshold the benefits from location in a region with extensive ties among individuals decline, and the firms can be negatively affected by overembeddedness (of firm or individuals) in the local environment (Uzzi, 1997).

Our three last predictions are based on the diverse properties of the two markets. Based on these properties, we hypothesize that firms will suffer more from the negative effects of very high levels of potential social capital in the case of involvement in the foreign markets for technology than in the case of the markets for goods. Moreover, we posit that firms that invest more in research and development (R\&D) obtain more involvement in foreign markets for goods for any level of potential social capital (positive moderation). In contrast, firms that invest less in research and development (R\&D) obtain more involvement in foreign markets for technology for any level of potential social capital (negative moderation). We use Italian Institute of Statistics (ISTAT) data for 1999 to explore differences in the levels of potential social capital across Italian regions. The items were collected at the individual level and aggregated to the regional level. To measure potential social capital, we selected a number of items that identify a mix of strong ties (e.g., friendship ties) and social participation (e.g., membership of voluntary associations) among the individuals within given regions. We combine these data with firm-level data to investigate our hypotheses.

This study makes three main contributions, each with a theoretical and an empirical component. First, although there is a substantial body of work in international business and geography that investigates the knowledge endowments of foreign locations, few studies examine the characteristics and levels of firms' involvement in the markets for exports of goods and technologies, and the characteristics (knowledge endowments) of their home locations. A notable exception is Cantwell and Janne (1999), which shows that subsidiaries whose parent companies' home locations can be characterized as "lower-order" technologically, tend to engage in technological activities similar to those in the home location, while the subsidiaries of multinational firms headquartered in "higherorder" technology locations tend to undertake activities that are technologically different. Cantwell and Janne examine search behavior in foreign locations, but not the mechanisms related to the home context that may induce greater involvement in foreign markets (or hinder firms' international activity). The present study provides novelty by demonstrating the importance of the home region's "knowledge characteristics" relative to the firm's degree of involvement in foreign markets.

Second, in this paper we compare and contrast the influence of home location on involvement in foreign markets, in two related but very different markets: the market for goods and the market for technology. Most studies in the literature focus on only one or other of these markets. Thus this study contributes to the emerging literature on the internationalization of intangible resources (e.g., Knight $\&$ Kim, 2009) and the functioning of the markets for technology (e.g., Arora, Fosfuri, \& Gambardella, 2001). Third, while research on social capital tends to focus on its benefits (e.g., Zhou et al., 2007), we argue that potential social capital facilitates firms' efforts to participate in international markets, but acknowledge the limits possibly set by "home" potential social capital. We argue that very high levels of regional potential social capital are likely to have negative consequences. Potential social capital can induce both embeddedness and overembeddedness (Uzzi, 1997).

\section{THEORETICAL BACKGROUD}

The international business literature shows that firms operating in foreign markets often encounter the "liability of foreignness", which increases the costs of foreign market activities (Dunning, 1977; Hymer, 1976; Zaheer, 1995). For this reason, firms tend to internationalize only when the host-country firm-specific advantages are sufficiently valuable to offset - or at least significantly reduce - these "unfamiliarity" costs (Buckley \& Casson, 1976; Zaheer, 1995). 
The regional systems of innovation approach argues that regional borders define how innovation and knowledge are created and diffused by strongly interrelated local actors (see, e.g., Asheim, 1996; Cooke, Clifton, \& Oleaga, 2005). Firms interact with other firms and with research institutes and financial and public institutions, and these interactions are enhanced by face-to-face and sustained contact (Gertler, 2003; Keeble \& Williamson, 1999). Local actors share values, norms, and standards with marked regional dimensions. The importance of geographical proximity is supported by empirical research on knowledge spillovers (Audretsch \& Feldman, 1996; Feldman, 1994; Jaffe, Trajtenberg, \& Henderson, 1993) and clusters (Iammarino \& McCann, 2006; Porter, 1990). Empirical research identifying the mechanisms enabling the flow of knowledge concludes that a context characterized by a rich set of relationships and social ties encourages knowledge and information exchange (Almeida \& Kogut, 1999; Breschi \& Lissoni, 2009; Saxenian, 1994; Stuart \& Sorenson, 2003).

Analyzing this set of social ties from a social capital perspective may enable a deeper understanding of social micro-mechanisms rooted in the geographical context that foster knowledge-sharing. This perspective highlights the role of the assets that inform these ties, such as trust, social norms, obligations, and shared communication codes. The literature on localized social capital builds on Coleman $(1988,1990)$ and Putnam et al. (1993). Coleman (1990) emphasizes that the presence of social relationships among individuals in a geographically bounded area engenders mutual trust. Putnam et al. (1993) identify the determinants of regional institutional efficiency in people's connections within their communities, showing that social capital promotes cooperation, encourages communication, and contributes to the creation of a trust-based environment characterized by respect for social norms. Social ties foster knowledge and resource sharing, increase the speed of problem identification, and reduce the time for monitoring partners. In the management literature, Nahapiet and Ghoshal (1998) and Tsai and Ghoshal (1998) clarify the notion of social capital (although they do not focus specifically on geographically constrained social capital) by breaking it down into three dimensions: structural, relational, and cognitive. The structural dimension refers to informal social interactions among individuals; the relational dimension refers to the assets, such as trust and credibility, embedded in those relationships; and the cognitive dimension refers to shared narratives, codes, and languages. While the relational and the cognitive dimensions may increase with the relational dimension (Tsai \& Ghoshal, 1998), they are distinct scopes. In our empirical investigation we focus only on the relational dimension.

As Nahapiet and Ghoshal (1998) note, the work by Putnam et al. (1993) was the inspiration for an extensive literature on social interactions and community participation. This body of work provides evidence of the existence of a positive relationship between social capital and economic performance in a geographically bounded area. Social capital is shown to facilitate collective learning and knowledge spillovers (Capello \& Faggian, 2005; Masciarelli, 2011), labor productivity (Sabatini, 2008), economic growth (Beugelsdijk \& Schaik, 2005; Knack \& Keefer, 1997), productivity based on R\&D investment and human capital (Tappeiner, Hauser, \& Walde, 2008), product innovation (Laursen, Masciarelli, \& Prencipe, 2012), and financial development (Guiso, Sapienza, \& Zingales, 2004). While most contributions in this literature show that geographical-level variations in social capital give rise to variations in performance at the same geographical level, in this paper, we claim that regional-level differences in (potential) social capital affect firms' international involvement.

We combine the international business and social capital approaches by arguing that the "unfamiliarity" costs of operating in foreign markets are - at least - alleviated by the characteristics of the home region related to potential social capital: The existence of extensive social networks in the focal firm's home region helps to promote foreign operations in terms of exports of goods and sales of technologies. Specifically, we use measures that reflect individuals' strong ties with other individuals, and their participation in social associations within their private spheres. We aggregate these measures up to the level of region to obtain a single regional-level measure of potential social capital (as in, e.g., Guiso et al., 2004, Putnam et al., 1993). Our argument is that variations in the level of social interaction across regions - reflected in strong ties with other individuals and their participation in social associations - signify the potential for knowledge flows, and that firms located in social-capital-rich regions, based on the private social ties of managers and employees, can more easily draw on information, knowledge, and other resources from within the same region. In turn, and 
as stated in the introduction, established social ties - facilitated by potential social capital - can facilitate the transfer of knowledge about firms' activities, between firms, and between firms and other institutions, and facilitate access to the resources needed to commercialize products and technologies in domestic or foreign markets. These arguments indicate that our analysis rests on the assumption - confirmed in the literature on localized economic activities - that personal and work relationships overlap. This literature shows that within geographical locations, multiple-level (professional and personal) networks eventually merge (Brusco, 1982; Saxenian, 1994). Saxenian (1994) argues that the success of Silicon Valley, compared with other regions such as Route 128 , is based on more vigorous exchange of ideas among individuals, firms, and other organizations, facilitated by a regional system of collaboration and learning (often informal in nature).

\section{HYPOTHESES}

Social Capital and Involvement in Foreign Markets for Goods and Technology

Our central claim is that location in a socially rich region increases the probability of establishing contacts with other organizations in the region - to learn from and to exchange resources with them. Potential social capital enables the transmission of information on local and non-local opportunities. Extensive social ties among individuals in a region, based on membership of a local organization for example, imply that firm managers and employees are more likely to interact informally with managers and employees from other firms and organizations in the same region. Local social networks can affect firms' involvement in foreign markets - both positively and negatively - for a number of reasons.

In relation to the positive effects, Zhou et al. (2007) synthesize the information advantages generated by firms' social networks in the context of involvement in foreign markets:

(1) knowledge of foreign market opportunities;

(2) advice and experiential learning;

(3) referral, trust, and solidarity involving third parties.

In this context, potential social capital acts as a transmission mechanism:

(a) allowing easier access to state-of-the-art knowledge and information held by local firms and organizations, useful for the development and commercialization of goods and technologies;

(b) promoting awareness of foreign market opportunities and information on how other local firms undertake internationalization activities in the markets for goods and technologies;

(c) identifying foreign exchange partners and providing access to tacit knowledge on international business practices (combined (a), (b) and (c) correspond to benefits (1) and (2) synthesized by Zhou et al., 2007).

However, potential social capital also promotes the forging of local social ties among organizations, which help to establish legitimacy and credibility, and facilitate the development of new capabilities needed to trade goods and technologies in foreign markets (corresponding to Zhou et al.'s benefit (3)). These include the capabilities related to product quality and complementary assets. In this context, reliance on networks facilitated by potential social capital may reduce the risks involved in exporting goods and technologies. The innovation literature shows that the degree of innovativeness of a firm's products and technologies depends on collaboration with external actors (see, e.g., Chesbrough, 2003; Laursen \& Salter, 2006; Rosenberg, 1982; von Hippel, 2005), and the geography literature shows that such collaboration is often geographically very localized (Cooke et al., 2005; Grabher, 1993; Porter, 2000; Powell, Koput, \& Smith-Doerr, 1996). Potential social capital opens up a range of prospects for and multiple channels of collaboration among the firms in a given region, and between firms and other organizations, thereby increasing the possibilities for collaboration aimed at increasing the attractiveness of a focal firm's products and technologies for export. Potential social capital may also enhance the chance of matching a local firm with another firm or organization with complementary assets, enabling access to international markets. The internationalization of $\mathrm{La}$ Breton, a small mechanics firm located in northern Italy, has been attributed to its social ties with ingenious and creative local suppliers with complementary assets (Mandurino, 2011).

Geographically localized potential social capital enhances the chances that ties will be established among firms; it is a disincentive for uncooperative behavior in inter-firm collaborations related to complementary assets. Reports of perverse behavior spread rapidly in regions characterized by extensive social ties, and the social punishment for this 
behavior may be severe. For example, in Castel Goffredo, a north Italian textile district, there was a verbal agreement among firms producing pantyhose that wage increases would not be offered to competitors' employees. When Filadoro, one of the larger firms in the area, began to violate this agreement, this behavior was made known to all the other firms involved, which then ostracized Filadoro (Lazerson \& Lorenzoni, 1999).

Although the above arguments suggest a positive relationship between potential social capital and firms' participation in the international markets for goods and technologies, if the level of potential social capital becomes too high it can trap firms within their local areas, and hinder search processes beyond the home region. This occurs for at least two reasons. One is related to the nature of social capital. Putnam and Goss (2002: 8) emphasize that

although the phrase "social capital" has a felicitous ring to it, we must take care to consider the potential vices of social capital, or even just the possibility that virtuous forms can have unintended consequences that are not socially desirable.

Putnam (2000: 22) states that there are "many different forms of social capital" including (betweengroup) bridging and (within-group) bonding. The empirical literature on industrial districts offers some examples of the different effects produced by these primary forms of social capital: bonding and bridging. According to Lazerson and Lorenzoni (1999), the crisis that characterized Prato's apparel district in the 1990s was due to excessive and overly tight local relationships (bonding social capital), which limited the ability of firms to address the needs of new national and international customers. Conversely, those firms that developed ties with firms outside the district - that is, created bridging social capital - survived the crisis (Lazerson \& Lorenzoni, 1999). Uzzi (1997) argues that too many strong bonding ties may not favor the network partners' abilities to construct bridges to the outside, and may reduce the inflow of innovative ideas, resulting in firms becoming "overembedded". In other words, when potential social capital becomes the basis for very high numbers of local social ties, identification of opportunities becomes confined to the local.

A second and related reason is based on Levinthal and March's (1993) claim that firms typically have a "tendency to ignore the bigger picture", and are inclined to privilege their nearest neighbors. A high level of potential social capital in the firm's home region may increase the resistance to explore foreign markets because of the very strong embeddedness of managers and employees in their local region. This higher likelihood that the focal firm's members will have strong ties in the local region is related also to higher levels of reciprocity in terms of loyalty and obligation to local partners. Thus firms in regions with very high levels of potential social capital may be more likely to prioritize local partners. Trigilia $(1986,1991)$ observes that the presence of very strong community bonds was one of the causes of the limited geographical scope of local firms' vision. Glasmeier (1994) claims that one of the causes of the Swiss watch industry's export contraction and consequent decline was an excessive number of local ties within the area, which led firms to ignore the advances being made in technology and markets. In the context of the Ruhr area in Germany, Grabher (1993) notes that repeated interactions among the same group of economic actors discouraged the search for new business activities and partners. High levels of regional potential social capital may confine firms to competing primarily with local firms, and ignoring more distant competitors (Baum \& Haveman, 1997). This limits the scope of environmental scanning, and induces myopia towards the behaviors of non-local competitors. According to Pouder and St John (1996), this was the reason for the insular "collective Detroit mind", a shared perception that non-local competitors (specifically, Japanese firms) were no threat to US automakers. The result can be that firms conduct very limited and biased searches for non-local information (Abrahamson \& Fombrun, 1994), which reduces their opportunities for internationalization.

In sum, we hypothesize that potential social capital linked to the local geography will have positive returns for firms' involvement in foreign markets only up to a threshold point, after which the returns from potential social capital start to decline. For the markets for goods and technology, we posit that:

Hypothesis 1a: Potential social capital is curvilinearly (inverted U-shape) related to firms' involvement in foreign goods markets.

Hypothesis 1b: Potential social capital is curvilinearly (inverted U-shape) related to firms' involvement in foreign technology markets. 
The term "technology" refers to broad knowledge about production methods, and to "knowledge rooted in engineering and scientific disciplines, which usually draws on practical experience from production" (Arora et al., 2001: 3). Given this, technology markets are characterized by a series of imperfections. The intrinsic characteristics of these markets generate several difficulties in terms of recognition, disclosure, and organization (Teece, 1981). Firms can create and accumulate technology that has applications in foreign markets. However, since the sale and purchase of technology are complicated processes, they require the home region firm to scan the international scene and make judgments about potential partners. The ability to participate in international technology markets often rests on the ability to collaborate directly with sellers or buyers at the international level, not just over the pure economic exchange of technology (Contractor, 1981). Also, technologies are not static, but are constantly evolving (Teece, 1981), which means that in order to continue to get the full benefit from a traded technology, the partners must establish continuous or recurrent cooperation. Close collaboration with international partners is imperative in the case of technology, since relying on local knowledge can be risky. As argued above, high numbers of local linkages can be a serious hindrance to the possibilities for developing (collaborative) linkages in the international market: Location in a region with a high level of potential social capital implies, for managers and employees, availability of and access to many local channels of interaction in the local region. Uzzi (1997: 49) argues that embeddedness works best as a resource allocation mechanism under "conditions of rapid product innovation". This suggests that the level of embeddedness will be higher in the case of technologies than in the case of goods, since rapid product innovation is an integral part of technology production. Given that a high level of embeddedness is a necessary condition for overembeddedness, extending this logic implies that when embeddedness is less important, as in the markets for goods, the chances of overembeddedness are correspondingly lower than in the case of the markets for technology. The markets for goods are "less imperfect", and a very strong focus on local interaction, induced by the level of social ties among individuals in the region, may be less damaging, given the lesser importance of direct collaboration with international partners than in the case of technologies. Assuming that potential social capital facilitates embeddedness, we can posit that:

Hypothesis 2: Firms will suffer more from the negative effects of very high levels of potential social capital in the case of involvement in foreign markets for technology than in the case of the markets for goods.

\section{The Moderating Effect of R\&D Investment}

\section{Goods}

Technological resources based on R\&D investment can produce competitive advantage in the form of differentiation and innovation, and the production of higher-quality or completely new products (Itami, 1987). The firm's capacity to modify its products is extremely important for participation in foreign markets; modification and adaptation are often necessary to satisfy international demand (Patel \& Vega, 1999). Also, because R\&D has a high fixed cost, innovative firms will gain relatively more than non-innovative firms from having a larger market. Therefore we can expect $R \& D$-active firms to be more export intensive (Basile, 2001). There is a substantial body of empirical research on firms' export behavior that demonstrates the importance of innovation investment, in the form of $R \& D$, as a major driver of firm success in export markets (e.g., Basile, 2001; Cassiman \& Golovko, 2011; Fernández \& Nieto, 2006; Ito \& Pucik, 1993; Knight \& Cavusgil, 2004).

We suggest that there is a complementarity effect between firms' R\&D investment and regional potential social capital, and the level of involvement in the markets for goods, such that for a given level of potential social capital in the form of social ties within the region, higher R\&D intensity will lead to higher levels of exports of goods. This is because:

(1) Provided that R\&D enhances the novelty and quality of the exported good, firms investing more in $\mathrm{R} \& \mathrm{D}$ will be able better to exploit the knowledge and resources acquired through local contacts based on social capital. We have argued that potential social capital in the local region acts as a transmission mechanism allowing firms easier access to resources in terms of stateof-the-art knowledge and information on other firms' internationalization activities in the markets for goods and technology, and more 
seamless access to complementary assets. These resources are more valuable when the exported products are competing on quality or novelty.

(2) Since R\&D investment is likely to enhance the firm's absorptive capacity (Cohen \& Levinthal, 1990), it will be better able to exploit the resources of other local firms and organizations to develop and commercialize goods.

We would suggest that:

Hypothesis 3: R\&D investment positively moderates the relationship between potential social capital and involvement in foreign markets for goods.

\section{Technology}

R\&D investment is likely to lead to more technologies that potentially could be sold in international markets. However, firms most often produce technologies to enable in-house production of goods (Fosfuri, 2006). Commercialization of a technology through its incorporation in a product or an internal process requires investment in complementary assets, such as "parallel technologies" and/or downstream infrastructure, including systems for supporting the delivery, sale, and servicing of output (McGrath, 1997; Teece, 1986). There is generally acknowledged to be much ex ante uncertainty regarding the need for and availability of these assets when investing in R\&D (McGrath, 1997). Accordingly, when R\&D investment ex post requires substantial investment in complementary assets, many firms do not have the internal resources to ensure successful commercialization of their inventions. As already argued, location in a region characterized by rich social ties among the employees of different firms facilitates firms' contacts with other organizations, and can ease resource limitations, establish legitimacy and credibility, and facilitate the development of new capabilities. Such a location also increases the likelihood that a firm's technological invention will be developed further in-house. Firms able to invest heavily in $R \& D$, that are located in a region with strong social interactions, are more likely to commercialize the technology in-house. On the other hand, major R\&D investment increases the probability of technological innovation, but in a context with few regional social ties, firms are more likely to be forced to sell the technology in foreign markets (rather than using or developing it in-house, which would require substantial investment in complementary assets). Firms in this context also are unable to exploit local social ties to draw on the resources needed for the commercialization of final products. Conversely, firms that produce a technology with minimal investment in R\&D will likely be less able to produce the complementary technologies required to commercialize the technology in a final product. If the firm is located in a region rich in social interactions, the personal links between the focal firm's employees and the employees of other organizations will likely enable learning from these other organizations, leading to the sale of the technology abroad. We would suggest that there is a substitution effect between firms' R\&D investment and regional potential social capital on the level of involvement in the markets for technology, so that for any given level of R\&D intensity, higher potential social capital in the form of social ties within the region should reduce the chances of involvement in foreign markets for technology:

Hypothesis 4: R\&D investment negatively moderates the relationship between potential social capital and involvement in foreign markets for technology.

\section{EMPIRICAL ANALYSIS}

\section{Face Validity}

To obtain face validity for our arguments related to the link between potential social capital and firms' involvement in foreign markets, we interviewed a number of exporting firms to ascertain whether they engage in informal exchange of information and knowledge with other local firms, organizations, and institutions. We focused especially on international activities. The firms interviewed belong to an aerospace cluster, Polo Aerospaziale, located in the Umbria region. This cluster is an appropriate empirical setting for our study for at least two reasons:

(1) Umbria has a good level of potential social capital.

(2) Consistent with our larger sample, the activities of the firms interviewed are manufacturingbased, involved in the production of mechanical and electronic components for aerospace, defense, and civil and military aviation.

We asked interviewees to indicate the sources of their learning about the possibilities for exporting; we asked whether they engaged in formal or informal 
discussion of their marketing efforts abroad with managing directors in their local region; and we asked whether these conversations had proved useful for their export efforts.

The interviews showed that firms do exchange information on their activities (including international activities) with local managers and entrepreneurs. Exchanges of information occur through formal and informal interactions, and are important for learning about foreign market opportunities and new marketing techniques and production methods. One interviewee said that:

\begin{abstract}
From talking to people from firms within the district, we have learned about the importance of international exhibitions for exports in this sector, including which are the most important exhibitions, how to present our products in these exhibitions and about the need to cooperate and to present ourselves as a part of the Polo Aerospaziale.
\end{abstract}

The interviews provided several examples of mutually beneficial knowledge-sharing that had enabled the firms to improve their products, which had made them more attractive to foreign customers. We also gathered more evidence on the importance of potential social capital in the early stages of the internationalization process. One of the firms interviewed had begun exporting only recently. Its products initially did not have the certification required by many foreign buyers. Social interactions with local partners allowed it to discover which foreign companies would be willing to buy its products without this certification. One interviewee told us that:

Thanks to our associates in the Polo Aerospaziale cluster, we got the names of some foreign firms that did not require that certification.

The firm was able to learn from firms that had had this problem in the past, and to begin exporting. Subsequently, social interaction provided it with information on obtaining this certification, which enabled it to increase its presence in the international market.

\section{Data Description}

Our empirical analysis relies on two main data sources: Italian firm-level manufacturing data on involvement in foreign markets, and regional-level data on potential social capital. The firm-level data are from the Survey of Manufacturing Firms conducted by Unicredit-Capitalia (an Italian banking group), covering the period 2001-2003. UnicreditCapitalia collects data on a large number of variables from a stratified random sample of more than
10,000 manufacturing firms with more than 10 employees. The design of the sampling plan subdivides the population into layers (strata). The sample was extracted from a population of approximately 70,000 firms, and represents about 7\% of total firms and $9 \%$ of total employees. The final sample is representative of Italian manufacturing firms across macro regions (i.e., northwest, northeast, center, south), the four Pavitt (1984) sectors (i.e., supplier dominated, scale intensive, science based, specialized supplier), and five firm-size bands (11-20, 21-50, 51-250, 251-500, over 500 employees) (Capitalia, 2006). The survey was conducted using a questionnaire instrument administered via telephone interviews, and achieved a response rate of $28.5 \%$. The number of observations with no missing values is 1978 firms for export of goods and 1971 firms for sales of technology abroad.

Regional-level data are from the Multi-scope Analysis conducted by the Italian National Institute of Statistics (ISTAT) in 1999. ISTAT provides valuable data on a stratified random sample of more than 24,000 families and more than 50,000 individuals. Face-to-face interviews were conducted with each family member, and the response rate was 82.5\%. ISTAT aggregates individual responses according to the 21 (NUTS 2) regional levels. Our measure of potential social capital consists of eight items involving four two-point scales, two fourpoint scales, one seven-point scale, and one count of voluntary organizations per region (for further details, see the Appendix). The reliability of the two-point scales is perhaps questionable, although such scales confer advantages in terms of simpler administration and scoring (Shupe \& Wolfer, 1966). However, potential reliability does not constitute a major problem in our case, since the questions do not require a qualitative judgment (i.e., like/ dislike), but refer to a concrete singular event, in this case whether or not citizens had undertaken a certain activity in the previous 12 months (e.g., attended a voluntary organization (yes/no)). Also, in the factor analysis we use responses aggregated by region and expressed as percentages of the individuals involved in a particular activity, implying that our items are continuous. In our view, the level of the 21 Italian regions is the most relevant level of aggregation for the present study, since the greatest variation in the level of social capital is likely to be between rather than within regions. For example, participation rates for political elections tend to vary across the 21 regions but to be similar within regions (i.e., across provinces within regions). 
We use Eurostat data to measure regional expenditure on $R \& D$ as a percentage of regional GDP, regional human capital, and population size.

\section{Research Strategy}

We investigate the effect of potential social capital on a firm's involvement in foreign markets, using a two-step empirical strategy. First, since potential social capital is a multidimensional concept (Guiso, Sapienza, \& Zingales, 2011; Putnam et al., 1993), we measure it using principal component analysis (PCA). Second, in order to understand the effect of potential social capital on a firm's involvement in foreign markets, we conduct Tobit and complementary logit analyses. Since two of our hypotheses are related to moderating effects, we test them through complex interactions involving squared terms.

For the most part we avoid the problem of common method bias, since our dependent variables are at firm level, and the key independent variable (potential social capital) was collected at the individual level and aggregated at the NUTS 2 regional level. To reduce the effects of consistency of the artifacts for the firm-specific variables, the survey was organized so that the questions related to outcome variables followed the questions related to the independent variables (Salancik \& Pfeffer, 1977). We perform a Harman one-factor test on the firm-level variables in the models in this paper to examine whether common method bias might be augmenting the relationships detected (Podsakoff \& Organ, 1986). Since we find multiple factors, and since the first factor does not account for the majority of the variance (the first factor accounts for only 19\% of the variance), we can state that there are no signs of common method bias.

\section{Measures}

\section{Dependent variables}

We use export intensity as the dependent variable to assess the degree of the firm's Involvement in foreign markets for goods. Export intensity is measured as the ratio of foreign to total sales, generally considered an appropriate measure of firm involvement in foreign markets (e.g., Fernández \& Nieto, 2006), since exporting is the most frequent firm internationalization strategy. Export intensity (export/sales) is a double-truncated variable, which by definition assumes values between 0 and 100 , and frequently is zero. For the firm's Involvement in foreign markets for technology, we measure the transmission by firms of codified knowledge. Flows of codified knowledge often occur through impersonal means, such as patents and licenses. Several studies consider patents and licenses to measure exploitation of know-how in foreign markets (Davidson \& McFetridge, 1985; Telesio, 1979). We measure firm participation in the international markets for technology using a dummy variable that takes the value 1 if the firm has sold a patent or licensed a technology in a foreign country, and 0 otherwise.

\section{Independent variables}

How to measure (potential) social capital and identify its sources and consequences has been a subject of debate (Portes \& Landolt, 1996). As mentioned earlier, Nahapiet and Ghoshal (1998) advocate distinguishing between the structural, relational, and cognitive dimensions of social capital. Following most research on social capital (e.g., Coleman, 1988; Portes, 1998; Putnam et al., 1993; Woolcock \& Narayan, 2000), we consider the structural dimension as the most appropriate for empirical analysis, since it differentiates between the sources and outcomes of social capital, and provides reliable measures.

We measure potential social capital using PCA. Our selection of the items to include in the PCA was guided by the theory and the empirical results. Consistent with the literature that considers social capital to be a collective asset (Guiso et al., 2004; Knack \& Keefer, 1997; Putnam et al., 1993), we regard the networks of social relationships in a given region as providing the actors in the region with easier access to information, knowledge, and resources. We measure the potential value of social capital by the features of the social ties among citizens in the firm's home region, as representing the determinants of social capital. These include networks, participation in the community, and membership of citizens' associations. In selecting the items to include in our measure, we rely on previous empirical work (Beugelsdijk \& Schaik, 2005; Hauser, Tappeiner, \& Walde, 2007; Laursen et al., 2012; Putnam et al., 1993). Our PCA items include variables that indicate strong ties (Meeting friends regularly; Social meetings; Satisfaction over relationships with friends), and participation in social associations (Participation in cultural associations; Participation in voluntary associations; Monetary donations to associations; Participation in non-voluntary organizations; Number of voluntary associations per region). The first set of items captures the social ties among citizens related to interacting with friends; 
the second set refers to regional participation in associations, which in turn creates the basis for local social ties. The selected items reflect the level of social ties identified by social capital theory as fundamental, and are used as proxies for social capital. For example, in their review of the social capital literature, Woolcock and Narayan (2000) highlight membership in informal and formal associations and networks as a commonly used measure of social capital. From the point of view of the focal firms in our sample, this construct implies that potential social capital facilitates the development and functioning of social ties, which may enable the focal firm to access and exchange information, knowledge, and resources (the distribution of potential social capital across Italian regions is displayed in Figure 1).

We find significant correlations between the items measuring strong social ties and participation in social associations. This confirms that they are measuring the same underlying component, and indicates the convergent validity of our measure of potential social capital. To corroborate this convergent validity, we perform an item-test correlation and an item-rest correlation. The item-test correlation shows how each item is correlated with the overall scale. We find that individual correlations range between 0.74 and 0.94 . The item-rest correlation, which shows how each item is correlated with a scale computed from only the other seven items, ranges from 0.67 to 0.91 . This confirms convergent validity. We can also confirm dis-

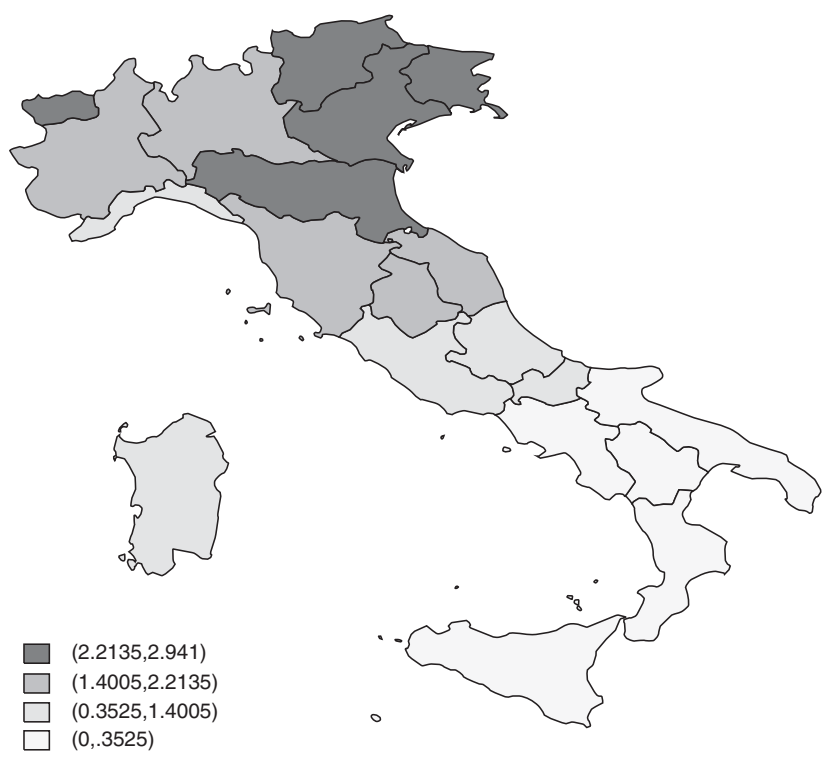

Figure 1 Social capital levels across Italian regions. Note: A darker color indicates a higher level of potential social capital. criminant validity, since the items measuring strong social ties and participation in social associations are relatively weakly correlated with political participation $(r=-0.27)$. For an indication of the reliability of our measure of potential social capital we compute Cronbach's alpha, which indicates the correlation between the observed and the true value. Cronbach's alpha is equal to 0.94 , which is above the widely accepted threshold of 0.70 (Nunnally, 1978), and demonstrates the good internal consistency of our measure.

We used the Bartlett test of sphericity and the Kaiser-Mayer-Olkin (KMO) criterion to assess whether the eight items were appropriate for PCA. The Bartlett test of sphericity is significant, and the KMO criterion exhibits a test statistic of 0.81 . This indicates that a PCA of the items is appropriate. We ran a non-parametric PCA on the eight social capital items listed above. The non-parametric PCA differs from the standard PCA in deriving Eigenvalues from a co-graduation matrix (Spearman's rho or rank order correlation coefficients). The procedure is aimed at minimizing the effects of outliers. From the PCA we extract one principal component that appears to capture the idea of potential social capital (eigenvalue $=5.99$ ). It explains $0.75 \%$ of the total variance. This result is considered satisfactory for an analysis of social variables. Table 1 presents this component, and reports the Eigenvalues and percentage of variance explained. Our regression analyses also include $R \& D$ intensity, which is a key moderating variable measured by the number of employees involved in $R \& D$ activities to the total number of employees.

\section{Control variables}

Previous research shows that firm innovation can have a positive impact on involvement in foreign markets (e.g., Basile, 2001; Cassiman \& Golovko, 2011). We therefore introduce Innovation as control variable, which is measured as a dummy variable that takes the value 1 if the firm introduced at least one innovation in the three years 2001-2003, and 0 otherwise. There is no consensus in the literature about how firm size relates to involvement in foreign markets, although it is acknowledged that this variable affects involvement in foreign markets (Bonaccorsi, 1992; Calof, 1994). The number of employees in 2001 captures firm Size. Firms' investment strategies have been shown to be correlated with involvement in foreign markets (Basile, 2001). Therefore we include two additional control variables, for Investment in ICT (measured as investment 
Table 1 Results of principal component analysis

\begin{tabular}{lcc}
\hline & \multicolumn{1}{c}{ Component1: Potential social capital } \\
\cline { 2 - 2 } & Factor loading & Commonalities \\
\hline Participation in cultural associations & 0.938 & 0.910 \\
Participation in voluntary associations & 0.908 & 0.680 \\
Participation in non-voluntary organizations & 0.912 & 0.950 \\
Number of voluntary associations per region & 0.849 & 0.900 \\
Money given to associations & 0.936 & 0.770 \\
Meeting friends regularly & 0.727 & 0.600 \\
Social meetings & 0.880 & 0.650 \\
Satisfaction over relationships with friends & 0.745 & 0.700
\end{tabular}

in information and communication technology over total sales) and International commercial agreements (a dummy variable taking the value 1 if the firm has established commercial agreements with firms in foreign countries in the three years 20012003, and 0 otherwise). The literature shows that these two variables are positively related to involvement in foreign markets (Fox, 2009). Additionally, since firms' involvement in foreign markets can be affected by type of ownership (family ownership has been found to be negatively related to firm internationalization; Fernández \& Nieto, 2006), we control for Firm ownership using a dummy variable that is equal to 1 if the firm is a family firm with one or more family members in managerial positions, and 0 otherwise. Firms benefit from investment in external $R \& D$ to leverage the resources and knowledge of competitors, suppliers, and other organizations (Pisano, 1990). This openness to external sources of resources and knowledge may have a positive effect on the firm's involvement in foreign markets. Therefore we control for Externally acquired $R \& D$, measured as its percentage in firm sales, to account for firm openness. Previous studies found substantial industry differences in firms' involvement in foreign markets (Gao, Murray, Kotabe, \& Lu, 2009). We account for this by including Industry export intensity, measured as mean export intensity by industry (Fernández \& Nieto, 2006), and four dummies for Supplier dominated, Scale intensive, Science based, and Specialized supplier, which describe the firm's principal activity. Since our key independent variable (potential social capital) is a regional variable, we need to ensure that it is not capturing other aspects of the firm's regional context. We do this by including regional control variables in the model. We control for Regional political participation (attendance at political meetings). This variable represents an important aspect of the regional social structure (Putnam et al., 1993), but in the Italian context it is difficult to theorize about its effect on firms' involvement in foreign markets. Researchers have emphasized that in Italy political parties are increasingly "personal machines" (Calise, 2000: 5), not always accountable to members and activists, or sensitive to appeals for collective action (Della Porta, 2004).

Previous work suggests that the regional knowledge base influences internationalization (Boschma \& Iammarino, 2009). We account for this by including controls for the percentage of the workforce with a science and technology degree, which measures Regional human capital, private firms' R\&D expenditure as a percentage of regional GDP (Regional private $R \& D / G D P)$, and Regional patenting intensity, measured as the number of patents registered with the European Patent Office per million inhabitants. We also control for region size, since the literature shows that larger regions have more options and more cosmopolitan attitudes (Florida, Mellander, \& Stolarick, 2008), which might affect firms' involvement in foreign markets. We measure region size through the logarithm of the number of residents in the given region (Population). Regional openness is important for firms' internationalization. We include a control variable, Airports, to measure regional infrastructure, measured as the number of passengers embarked and disembarked by air per 100 inhabitants, to account for the general "openness" of the region, which may reflect out-ofregion boundary-spanning (Gambardella, Mariani, \& Torrisi, 2009). We control also for Industry concentration using a Herfindahl-type measure. Greenaway and Kneller (2007) suggest that this variable might have a positive effect on firms' involvement in foreign markets, since firms can share information 
with other firms in the same industry, increasing the likelihood of internationalization. Finally, we include the variable Airports in neighboring regions to account for the possible effects of neighboring regions on the firm's involvement in foreign markets. Table 2 presents the descriptive statistics and correlations among our variables.

\section{Results}

The most popular approach to deal with the problem of censored samples is the Tobit model with a "corner solution" interpretation (Wooldridge, 2002). This model uses all the available information from the explanatory variables, including those where the dependent variable is zero. Table 3 presents the results of the Tobit estimations: Model I includes only the key independent variables; Model II includes only the control variables; Models III and IV include both the independent and the control variables.

We find support for Hypothesis 1a. The parameter for potential social capital is significant and positive for explaining export intensity, showing that potential social capital contributes to explaining the internationalization of goods. Also, potential social capital squared is negative and significant, showing that export intensity increases with potential social capital up to a certain point. When this point is passed and the level of regional social capital becomes too high, export intensity diminishes. Figure 2 is based on the estimations presented in Model III, and displays the predictions of the empirical model for the relationship between potential social capital and export intensity. Figure 2 shows that the point where potential social capital has negative consequences for export intensity - what might be called the "tipping point" - is at 1.9 on the potential social capital scale (maximum score is 2.9). In other words, when a firm is located in a region whose potential social capital is greater than 1.9, negative effects overtake positive effects: 878 of the 1978 firms are to the right of the tipping point.

Firm involvement in foreign markets for technology is measured by a dummy variable that takes the value 1 if the firm has experience in international technology markets in selling patents and licenses. This experience seems rare, and applies to only $0.01 \%$ of the firms in our sample. To deal with this problem we use a complementary logit model. Complementary log-log models are commonly used when the probability of an event is very small. Unlike logit and probit models, complementary log-log functions are asymmetrical. The log-likelihood function for the complementary $\log -\log$ is

$$
\ln L=\Sigma w_{j} \ln F(x, j, b)+\Sigma w_{j} \ln [1-F(x, j, b)]
$$

where $F(z)=1-\exp [-\exp (z)]$, and $w_{j}$ denotes the optional weights.

Table 3 presents the results of the complementary logit estimations. In the models that include the key independent variables and the controls (Models VII and VIII), the potential social capital parameter is positive and significant, and the potential social capital squared parameter is negative and significant, which supports Hypothesis 1b concerning firms' participation in international technology markets. The graph of the relationship between potential social capital and involvement in foreign technology markets (Figure 3) shows that the tipping point is at 1.7 on the potential social capital scale (the graph is based on the estimations in Model VII). There are 1600 firms to the right of the tipping point.

The evidence provides support for Hypothesis 2 since, in the case of markets for technology, the number of firms above the tipping point is 1600 as compared with 878 firms in the case of markets for goods. Also, the downward-sloping part of the curve is much steeper in the case of foreign technology markets (Figure 3) than in the foreign markets for goods (Figure 2).

To test Hypothesis 3, we introduce two interaction effects $(R \& D \times$ Potential social capital and $R \& D \times$ Regional social capital ${ }^{2}$ ) to examine this complex interaction (Jaccard, Wan, \& Turrisi, 1990). Model IV in Table 3 shows that the parameter for $R \& D \times$ Potential social capital is negative and statistically significant for firms' participation in the international markets for goods, and the parameter for $R \& D \times$ Potential social capital $^{2}$ is positive and statistically significant. Taken together, these findings suggest that the shape of the quadratic relationship changes at different levels of investment in $R \& D$ (Jaccard et al., 1990: 59), although the degree of statistical significance is not high.

To understand the moderating effects of R\&D on the quadratic relationship between potential social capital and export intensity, we reduced the Tobit equation in Model IV by substituting "representative" values for firm R\&D (at the 25th and 75th percentiles) and replacing all other predictors with 
Table 2 Descriptive statistics and correlation matrix

\begin{tabular}{|c|c|c|c|c|c|c|c|c|c|c|c|c|c|c|c|c|c|c|c|c|c|c|c|c|c|c|c|}
\hline & & Mean & s.d. & Min & $\operatorname{Max}$ & 1 & 2 & 3 & 4 & 5 & 6 & 7 & 8 & 9 & 10 & 11 & 12 & 13 & 14 & 15 & 16 & 17 & 18 & 19 & 20 & 21 & 22 \\
\hline 1 & $\begin{array}{l}\text { Involvement in } \\
\text { international market } \\
\text { for goods }\end{array}$ & 32.92 & 30.44 & 0.00 & 100.00 & & & & & & & & & & & & & & & & & & & & & & \\
\hline 2 & $\begin{array}{l}\text { Involvement in } \\
\text { international market } \\
\text { for technology }\end{array}$ & 0.01 & 0.10 & 0.00 & 1.00 & 0.05 & & & & & & & & & & & & & & & & & & & & & \\
\hline 3 & $\begin{array}{l}\text { Potential social } \\
\text { capital }\end{array}$ & 1.85 & 0.69 & 0.00 & 2.94 & 0.11 & 0.02 & & & & & & & & & & & & & & & & & & & & \\
\hline 4 & $R \& D$ intensity & 0.04 & 0.07 & 0.00 & 0.96 & 0.14 & 0.04 & 0.06 & & & & & & & & & & & & & & & & & & & \\
\hline 5 & Innovation & 0.73 & 0.44 & 0.00 & 1.00 & 0.14 & 0.03 & 0.02 & 0.23 & & & & & & & & & & & & & & & & & & \\
\hline 6 & Size & 118.62 & 359.44 & 4.00 & 12199 & 0.16 & 0.02 & 0.04 & -0.02 & 0.10 & & & & & & & & & & & & & & & & & \\
\hline 7 & Investment in ICT & 0.02 & 0.18 & 0.00 & 7.78 & 0.03 & 0.00 & -0.01 & 0.02 & 0.02 & 0.01 & & & & & & & & & & & & & & & & \\
\hline 8 & $\begin{array}{l}\text { Int. commercial } \\
\text { agreements }\end{array}$ & 0.20 & 0.40 & 0.00 & 1.00 & 0.16 & 0.13 & -0.03 & 0.12 & 0.13 & 0.06 & 0.00 & & & & & & & & & & & & & & & \\
\hline 9 & Firm ownership & 0.14 & 0.35 & 0.00 & 1.00 & 0.02 & 0.02 & -0.03 & 0.00 & 0.02 & 0.02 & -0.01 & 0.01 & & & & & & & & & & & & & & \\
\hline 10 & $\begin{array}{l}\text { Externally acquired } \\
R \& D\end{array}$ & 10.97 & 24.22 & 0.00 & 100.00 & 0.07 & 0.01 & 0.02 & 0.09 & 0.15 & 0.08 & -0.01 & 0.09 & 0.04 & & & & & & & & & & & & & \\
\hline 11 & $\begin{array}{l}\text { Industry export } \\
\text { intensity }\end{array}$ & 38.69 & 12.48 & 3.57 & 81.00 & 0.44 & 0.08 & 0.09 & 0.13 & 0.12 & 0.09 & 0.02 & 0.09 & 0.02 & 0.06 & & & & & & & & & & & & \\
\hline 12 & Supplier dominated & 0.51 & 0.50 & 0.00 & 1.00 & -0.07 & -0.05 & -0.04 & -0.12 & -0.09 & -0.04 & -0.04 & -0.04 & 0.01 & -0.02 & -0.16 & & & & & & & & & & & \\
\hline 13 & Scale intensive & 0.16 & 0.37 & 0.00 & 1.00 & -0.18 & -0.02 & -0.07 & -0.08 & -0.03 & -0.01 & -0.01 & -0.05 & 0.00 & -0.02 & -0.33 & -0.45 & & & & & & & & & & \\
\hline 14 & Science based & 0.05 & 0.21 & 0.00 & 1.00 & 0.00 & 0.03 & -0.06 & 0.21 & 0.06 & 0.04 & 0.01 & 0.02 & -0.01 & 0.03 & 0.07 & -0.22 & $2-0.10$ & & & & & & & & & \\
\hline 15 & Specialized suppliers & 0.28 & 0.45 & 0.00 & 1.00 & 0.23 & 0.06 & 0.14 & 0.10 & 0.10 & 0.03 & 0.04 & 0.08 & 0.00 & 0.02 & 0.41 & -0.64 & $4-0.28$ & -0.14 & & & & & & & & \\
\hline 16 & $\begin{array}{l}\text { Regional political } \\
\text { participation }\end{array}$ & 1.47 & 0.34 & 0.60 & 2.40 & -0.03 & 0.01 & -0.27 & -0.04 & 0.00 & -0.03 & 0.02 & 0.00 & 0.02 & -0.04 & -0.03 & -0.01 & 0.02 & -0.01 & 0.00 & & & & & & & \\
\hline 17 & $\begin{array}{l}\text { Regional human } \\
\text { capital }\end{array}$ & 6.40 & 1.68 & 0.40 & 11.70 & 0.04 & 0.00 & 0.30 & 0.08 & -0.01 & 0.00 & 0.00 & -0.07 & -0.02 & 0.01 & 0.08 & -0.11 & -0.02 & 0.04 & 0.12 & 0.07 & & & & & & \\
\hline 18 & $\begin{array}{l}\text { Regional private } \\
R \& D / G D P\end{array}$ & 0.57 & 0.37 & 0.01 & 1.32 & 0.04 & 0.04 & 0.36 & 0.04 & 0.02 & 0.03 & 0.02 & 0.00 & 0.02 & 0.01 & 0.03 & -0.14 & $4 \quad 0.01$ & 0.03 & 0.13 & 0.02 & 0.17 & & & & & \\
\hline 19 & $\begin{array}{l}\text { Regional patenting } \\
\text { intensity }\end{array}$ & 99.54 & 44.39 & 2.80 & 152.00 & 0.07 & 0.02 & 0.60 & 0.07 & 0.02 & 0.03 & 0.02 & -0.03 & 0.01 & 0.00 & 0.08 & -0.14 & $4-0.03$ & -0.02 & 0.18 & 0.19 & 0.61 & 0.46 & & & & \\
\hline 20 & Population & 15.24 & 0.71 & 12.69 & 16.01 & 0.03 & -0.02 & -0.06 & 0.03 & -0.03 & -0.01 & 0.03 & -0.04 & 0.01 & -0.02 & 0.04 & -0.11 & 0.04 & 0.01 & 0.09 & 0.21 & 0.48 & 0.22 & 0.52 & & & \\
\hline 21 & Airports & 137.63 & 107.31 & 0.00 & 475.40 & 0.01 & -0.01 & -0.14 & 0.02 & 0.01 & 0.00 & 0.04 & -0.01 & 0.02 & -0.01 & 0.02 & -0.11 & 0.05 & 0.07 & 0.05 & 0.25 & 0.28 & 0.18 & 0.35 & 0.73 & & \\
\hline 22 & Industry diversity & 0.15 & 0.03 & 0.12 & 0.40 & -0.13 & 0.05 & -0.39 & -0.06 & 0.01 & -0.05 & 0.00 & 0.01 & 0.02 & -0.05 & -0.17 & 0.03 & $3 \quad 0.08$ & -0.01 & -0.09 & 0.23 & -0.39 & -0.12 & -0.32 & -0.18 & -0.03 & \\
\hline 23 & $\begin{array}{l}\text { Airports in } \\
\text { neighboring regions }\end{array}$ & 133.86 & 60.04 & 0.00 & 278.06 & 0.00 & -0.01 & 0.26 & 0.01 & -0.03 & 0.01 & -0.03 & 0.02 & -0.04 & 0.02 & 0.01 & 0.05 & $5-0.03$ & -0.05 & -0.01 & -0.43 & -0.15 & -0.03 & -0.16 & -0.41 & -0.68 & -0.30 \\
\hline
\end{tabular}

Note: Correlation coefficients above $|0.04|$ are significant at the two-tailed, $5 \%$ level of significance. 
Table 3 Results of the regression models, explaining sales of goods in foreign markets

\begin{tabular}{|c|c|c|c|c|c|c|c|c|}
\hline & & & \multicolumn{4}{|c|}{ Tobit } & & \\
\hline & & & & oods-perc & ent of sales & & & \\
\hline & \multicolumn{2}{|c|}{ Model I } & \multicolumn{2}{|c|}{ Model II } & \multicolumn{2}{|c|}{ Model III } & \multicolumn{2}{|c|}{ Model IV } \\
\hline & Coeff. & s.e. & Coeff. & s.e. & Coeff. & s.e. & Coeff. & s.e. \\
\hline Potential social capital & $15.181^{\star * *}$ & $(3.710)$ & & & $23.356^{* *}$ & $(7.636)$ & $26.771^{* * *}$ & $(7.942)$ \\
\hline Potential social capital $^{2}$ & $-3.454^{* *}$ & $(1.316)$ & & & $-5.618^{*}$ & $(2.392)$ & $-6.950 * *$ & $(2.522)$ \\
\hline$R \& D$ intensity & $1.104^{\star *}$ & $(0.426)$ & & & $0.363^{* * *}$ & $(0.108)$ & $0.785^{\dagger}$ & $(0.402)$ \\
\hline$R \& D$ intensity $\times$ Regional social cap. & -0.866 & $(0.566)$ & & & & & $-1.000^{\dagger}$ & $(0.581)$ \\
\hline$R \& D$ intensity $\times$ Regional social cap. ${ }^{2}$ & $0.347^{\dagger}$ & $(0.190)$ & & & & & $0.376^{\dagger}$ & $(0.195)$ \\
\hline Innovation & & & $7.564^{\star * *}$ & $(1.840)$ & $6.045^{\star \star \star}$ & $(1.876)$ & $5.998^{\star * *}$ & $(1.875)$ \\
\hline Size & & & $0.008^{\dagger}$ & $(0.004)$ & $0.008^{*}$ & $(0.004)$ & $0.008^{\dagger}$ & $(0.004)$ \\
\hline Investment in ICT & & & $3.171^{*}$ & $(1.573)$ & $2.993^{*}$ & $(1.317)$ & $3.080^{*}$ & $(1.400)$ \\
\hline Int. commercial agreements & & & $11.318^{* * *}$ & $(1.665)$ & $11.001 * * *$ & $(1.677)$ & $11.030^{\star * *}$ & $(1.674)$ \\
\hline Firm ownership & & & 0.037 & $(2.059)$ & 0.545 & $(2.105)$ & 0.685 & $(2.104)$ \\
\hline Externally acquired R\&D & & & 0.037 & $(0.032)$ & 0.038 & $(0.032)$ & 0.037 & $(0.032)$ \\
\hline Industry export intensity & & & $1.196^{* * *}$ & $(0.068)$ & $1.176^{\star \star *}$ & $(0.068)$ & $1.173^{* * *}$ & $(0.068)$ \\
\hline Supplier dominated & & & -1.830 & $(1.868)$ & -1.495 & $(1.875)$ & -1.415 & (1.874) \\
\hline Scale intensive & & & $-8.032^{\star \star}$ & $(2.515)$ & $-7.434^{* *}$ & $(2.505)$ & $-7.403^{* *}$ & (2.507) \\
\hline Science based & & & $-8.971^{*}$ & $(4.012)$ & $-9.743^{*}$ & $(4.213)$ & $-9.653^{*}$ & $(4.241)$ \\
\hline Specialized suppliers & & & \multicolumn{2}{|c|}{ Benchmark } & \multicolumn{2}{|c|}{ Benchmark } & \multicolumn{2}{|c|}{ Benchmark } \\
\hline Regional political participation & & & -2.610 & $(2.469)$ & -0.371 & $(2.737)$ & -0.479 & $(2.737)$ \\
\hline Regional human capital & & & $-1.195^{\dagger}$ & $(0.611)$ & $-1.969^{*}$ & $(0.795)$ & $-1.960^{* *}$ & $(0.792)$ \\
\hline Regional private $R \& D / G D P$ & & & 2.040 & $(2.318)$ & 1.196 & $(2.374)$ & 1.099 & (2.373) \\
\hline Regional patenting intensity & & & 0.038 & $(0.026)$ & -0.056 & $(0.037)$ & -0.056 & $(0.036)$ \\
\hline Population & & & 0.740 & $(1.776)$ & $4.306^{*}$ & $(2.055)$ & $4.354^{*}$ & $(2.062)$ \\
\hline Airports & & & -0.019 & $(0.013)$ & -0.015 & $(0.013)$ & -0.015 & $(0.014)$ \\
\hline Industry concentration & & & $-113.932^{\star *}$ & $(32.986)$ & -40.184 & $(39.861)$ & -38.796 & $(39.662)$ \\
\hline Airports in neighboring regions & & & $-0.045^{\star *}$ & $(0.020)$ & -0.015 & $(0.024)$ & -0.016 & $(0.023)$ \\
\hline Constant & $7.331^{\star *}$ & 2.427 & -8.716 & $(25.855)$ & $-83.063^{\star *}$ & $(33.593)$ & $-84.894^{\star *}$ & $(33.716)$ \\
\hline Number of observations & 3281 & & 1997 & & 1978 & & 1978 & \\
\hline$R^{2}$ & 0.005 & & 0.035 & & 0.036 & & 0.037 & \\
\hline F statistics & $23.04^{* * *}$ & & $40.48^{\star * *}$ & & $36.69^{* * *}$ & & $33.96^{\star * *}$ & \\
\hline
\end{tabular}

${ }^{\dagger} p<0.10 ;{ }^{*} p<0.05 ;{ }^{* *} p<0.01 ;{ }^{* *} p<0.001$. Two-tailed tests of significance. Standard errors in parentheses.

their respective variable means (Cohen \& Cohen, 1983; Jaccard et al., 1990; Schick \& Ponemon, 1993). Figure 4 provides graphs of this relationship, which suggest that firms with high levels of R\&D investment are better able to exploit potential social capital for any given level of potential social capital, and accordingly this result provides support for Hypothesis 3.

Pertaining to sales of technological knowledge, in Table 4, Model VIII, the parameter for $R \& D \times$ Potential social capital is negative and significant, while $R \& D \times$ Potential social capital $^{2}$ is positive and significant. We use these results to test Hypothesis 4 . When we reduce the complementary logit model by substituting representative values for firm R\&D (at the 25th and 75th percentiles) and replace all other predictors with their respective variable means (see Figure 5), we find that, in general, firms investing in R\&D tend to be less likely to sell their technologies internationally for any given level of potential social capital. This is in line with Hypothesis 4.

\section{Robustness Checks}

To check the robustness of our results, we specify some alternative econometric models. The results are not presented here, but are available on request from the authors. For firms' participation in the international markets for goods, we estimated a fractional response model (Papke \& Wooldridge, 1996). This is a frequently used alternative model if the dependent variable is a percentage variable 


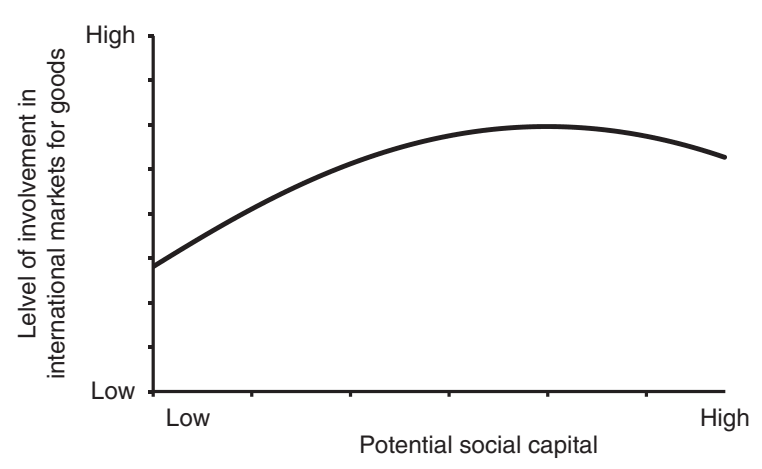

Figure 2 Predicted relationship between firms' export intensity and potential social capital.

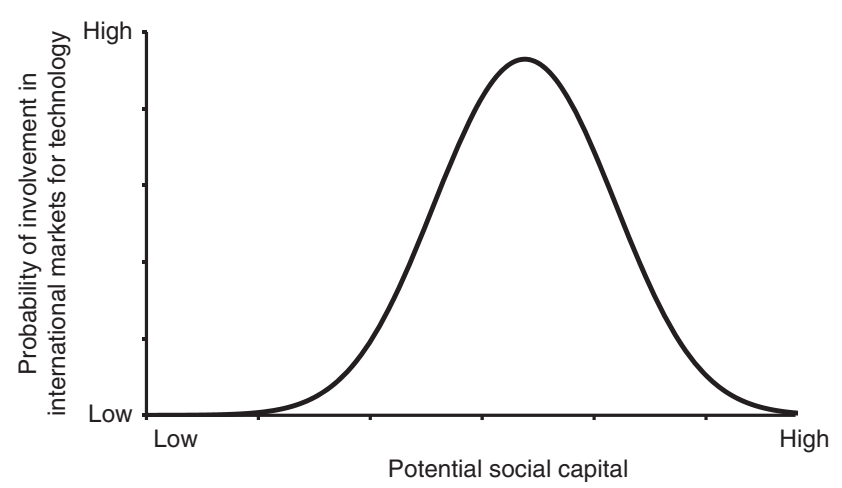

Figure 3 Predicted relationship between firms' involvement in foreign markets for technology and potential social capital.

with many limit observations - as in the case of our goods variable (see, e.g., Roper, Love, \& Higon, 2006; Wagner, 2001). The results of this specification are almost identical to the results in Table 3. For firms' participation in international markets for technology we tested the robustness of our findings by estimating logistic and probit models as alternatives to the complementary log-log specification. Again, the results obtained are consistent with the findings in Table 4 for the complementary log-log model.

Although our models include several region-level and industry-level controls, possible unobserved regional and industry heterogeneity might be a concern. Given that we use (in particular) regionlevel variables, for econometric reasons we cannot directly include a set of regional dummies in the model. In order to test whether our results are affected by heterogeneity, we use a two-stage approach for both goods and technology. In the first stage, we estimate models similar to those in Tables 3 and 4,

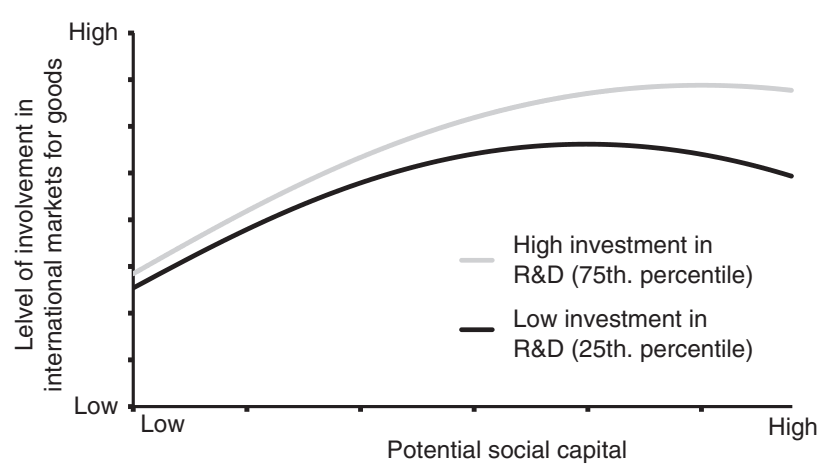

Figure 4 Predicted relationship between firms' export intensity and potential social capital moderated by R\&D intensity.

using the same estimators (respectively Tobit, and the complementary log-log model), but with regional and industry dummy variables as the only regressors. The latter are classified according to the two-digit industry codes. From these first-stage regressions we extract the residuals, which become the dependent variables in the second-stage estimations. The results of this procedure confirm the results in Tables 3 and 4 . The relation between the social interaction component of regional social capital and the internationalization of goods is still an inverted U-shape. In the case of internationalization of technology, the results of the second-stage estimation confirm our results: regional social capital has an inverted U-shaped relationship with firms' participation in the international markets for technology. All the parameters related to the Ushapes are significant at the $1 \%$ level. A possible problem with the two-stage approach is that the (predicted) dependent variable in the second stage is estimated with errors (Hardin, 2002). However, the fact that all our results are consistent (with and without the two-stage approach) tends to confirm their robustness. Thus unobserved regional and industry heterogeneity is unlikely to be driving the outcome.

To take account of possible effects of neighboring regions on firm performance, we compute the variables Potential social capital in neighboring regions and Airports infrastructure in neighboring regions. For regions with more than one neighbor, we use the average value. For the islands of Sicily and Sardinia, we consider as neighbors the regions of Calabria and Lazio respectively. Calabria is the most proximate to Sicily, and the mobility of people between these two regions is high. Lazio is the closest port 
Table 4 Results of the regression models, explaining sales of technologies in foreign markets

\begin{tabular}{|c|c|c|c|c|c|c|c|c|}
\hline & & & \multicolumn{4}{|c|}{ Complementary logit } & & \\
\hline & & & & Technolo & jies, dummy & & & \\
\hline & \multicolumn{2}{|c|}{ Model V } & \multicolumn{2}{|c|}{ Model VI } & \multicolumn{2}{|c|}{ Model VII } & \multicolumn{2}{|c|}{ Model VIII } \\
\hline & Coeff. & s.e. & Coeff. & s.e. & Coeff. & s.e. & Coeff. & s.e. \\
\hline Potential social capital & $3.375^{\star}$ & $(1.349)$ & & & $8.049 * *$ & $(2.776)$ & $11.895^{* *}$ & $(4.648)$ \\
\hline Potential social capital $^{2}$ & $-1.038^{*}$ & $(0.419)$ & & & $-2.357^{\star}$ & $(1.067)$ & $-3.519^{*}$ & $(1.550)$ \\
\hline$R \& D$ intensity & $0.149^{* *}$ & $(0.050)$ & & & 0.001 & $(0.002)$ & $0.316^{* *}$ & $(0.103)$ \\
\hline$R \& D$ intensity $\times$ Regional social cap. & $-0.205^{\star}$ & $(0.098)$ & & & & & $-0.438^{* *}$ & $(0.149)$ \\
\hline R\&D intensity $\times$ Regional social cap. ${ }^{2}$ & $0.067^{*}$ & $(0.034)$ & & & & & $0.135^{\star *}$ & $(0.047)$ \\
\hline Innovation & & & 0.089 & $(0.669)$ & -0.080 & $(0.692)$ & -0.052 & $(0.664)$ \\
\hline Size & & & 0.000 & $(0.000)$ & 0.000 & $(0.000)$ & 0.000 & $(0.000)$ \\
\hline Investment in ICT & & & -0.343 & $(1.663)$ & -0.444 & $(2.589)$ & -0.420 & $(2.969)$ \\
\hline Int. commercial agreements & & & $2.067^{* * *}$ & $(0.550)$ & $2.082^{\star \star *}$ & $(0.580)$ & 2.128 & $(0.612)$ \\
\hline Firm ownership & & & 0.298 & $(0.652)$ & 0.269 & $(0.665)$ & $0.375^{* * *}$ & $(0.646)$ \\
\hline Externally acquired R\&D & & & 0.000 & $(0.008)$ & 0.001 & $(0.010)$ & 0.001 & $(0.010)$ \\
\hline Industry export intensity & & & $0.074^{* * *}$ & $(0.020)$ & $0.073^{* * *}$ & $(0.022)$ & $0.075^{\star *}$ & $(0.024)$ \\
\hline Supplier dominated & & & -0.436 & $(0.651)$ & -0.350 & $(0.665)$ & -0.201 & $(0.687)$ \\
\hline Scale intensive & & & 0.294 & $(0.810)$ & 0.275 & $(0.809)$ & 0.450 & $(0.829)$ \\
\hline Science based & & & 0.028 & $(0.490)$ & 0.135 & $(0.475)$ & -0.227 & $(0.539)$ \\
\hline Specialized suppliers & & & \multicolumn{2}{|c|}{ Benchmark } & \multicolumn{2}{|c|}{ Benchmark } & \multicolumn{2}{|c|}{ Benchmark } \\
\hline Regional political participation & & & -0.129 & $(0.530)$ & -0.726 & $(0.992)$ & -0.836 & $(1.020)$ \\
\hline Regional human capital & & & 0.049 & $(0.120)$ & -0.330 & $(0.225)$ & -0.297 & $(0.243)$ \\
\hline Regional private $R \& D / G D P$ & & & 0.933 & $(0.639)$ & 1.131 & $(0.619)$ & 1.169 & $(0.635)$ \\
\hline Regional patenting intensity & & & 0.006 & $(0.006)$ & 0.006 & $(0.018)$ & 0.007 & $(0.019)$ \\
\hline Population & & & -0.264 & $(0.450)$ & 0.804 & $(0.877)$ & 0.660 & $(0.954)$ \\
\hline Airports & & & -0.002 & $(0.003)$ & -0.011 & $(0.004)$ & -0.011 & $(0.004)$ \\
\hline Industry concentration & & & $16.653^{\star *}$ & $(5.453)$ & $35.683^{* * *}$ & $(9.014)$ & $36.310^{*}$ & $(10.760)$ \\
\hline Airports in neighboring regions & & & -0.003 & $(0.006)$ & -0.004 & $(0.006)$ & -0.004 & $(0.006)$ \\
\hline Constant & $-7.227^{* * *}$ & 1.370 & -7.960 & $(7.027)$ & $-28.450^{\star}$ & $(13.947)$ & $-29.750^{*}$ & $(15.043)$ \\
\hline Number of observations & 3271 & & 1990 & & 1971 & & 1971 & \\
\hline$R^{2}$ & 0.063 & & 0.46 & & 0.48 & & 0.493 & \\
\hline$\chi^{2}$ & $61.06^{\dagger}$ & & $96.01^{* * *}$ & & $125.08^{* * *}$ & & $150.74^{\star * *}$ & \\
\hline
\end{tabular}

${ }^{\dagger} p<0.10 ;{ }^{*} p<0.05 ;{ }^{* *} p<0.01 ;{ }^{* * *} p<0.001$. Two-tailed tests of significance. Standard errors in parentheses.

to Sardinia. The inclusion of these variables in our regression analysis produces results consistent with our previous findings. There is an inverted U-shaped relationship between potential social capital and a firm's involvement in foreign markets (in both foreign goods and technology markets). In both the Tobit and conditional logit models, the potential social capital variable is positive and significant ( $p=0.049$ in the Tobit model, and $p=0.028$ in the conditional logit model), and potential social capital squared is negative and significant $(p=0.046$ in the Tobit model; $p=0.016$ in the conditional logit model). Also, the effect of R\&D in moderating the relationship between potential social capital and the firm's involvement in foreign markets is consistent with our previous findings. However, we identified some multicollinearity problems. Potential social capital in neighboring regions and potential social capital are highly correlated (0.87) and the VIF value, computed using an OLS model, equals 16.8, above the recommended threshold of 10 (Belsey, Kuh, \& Welsch, 1980). For this reason, the regression tables report the results without including the neighboring social capital variable.

\section{DISCUSSION AND CONCLUSIONS}

We set out to study the role of home potential social capital on firms' involvement in foreign markets for goods and technology. Our analytical framework builds on social capital theory, knowledge flows/spillovers, and international business literatures. We theorized and found empirical support for 


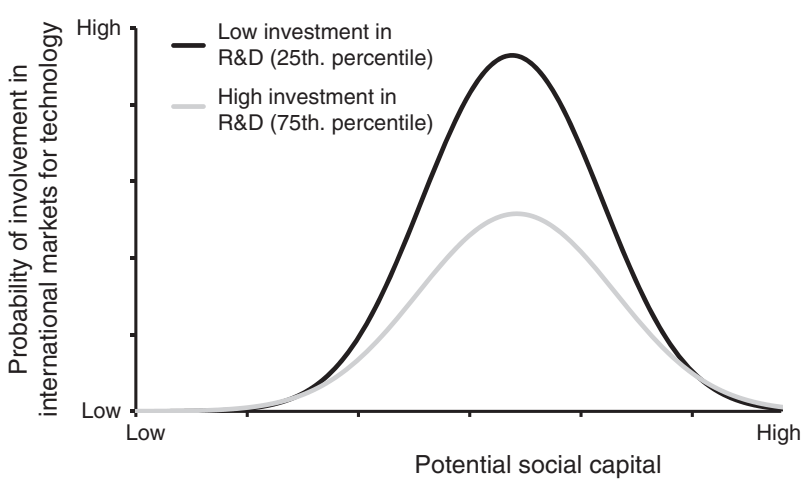

Figure 5 Predicted relationship between firms' involvement in foreign markets for technology and potential social capital moderated by $R \& D$ intensity.

an inverted U-shaped relationship between potential social capital and involvement in foreign markets: involvement in foreign markets increases with potential social capital up to a point, which, once passed, induces reduced involvement in foreign markets. The characteristics of the geographical region in terms of social capital both help and constrain the abilities of local firms to be internationally active. We suggested that the underlying mechanism is based on a high level of social ties in a region, creating multiple channels for contacts among managers and employees of firms and other organizations in the local area. The existence of multiple channels makes it easier for firms to obtain knowledge about opportunities in the form of trade information, knowledge of artifacts, and other resources, from other local organizations participating in local and international markets. Although this mechanism has not previously been explored, the findings are consistent with the literature on the role of the geographical context in firm performance (e.g., Asheim, 1996; Gertler, 2003; Porter, 2000). Our research also supports the idea that a very high level of potential social capital invariably results in an increase in the firm's attention to domestic issues, because the sheer number of local channels available to the firm may increase the likelihood that it will interact only with local actors.

We identified tipping points related to the markets for goods and technology, and found that potential social capital seems to induce more overembeddedness for technology markets than goods markets. We suggest that the reason for this is the different nature of the transacted objects: technological knowledge is context-specific, sticky, and therefore difficult to transfer and replicate. In other words, selling technological knowledge requires frequent and repeated interactions between vendor and buyer. This particularity of technology trade compared with trade in products not only makes embeddedness in the local environment more likely, it also makes strong reliance on local partners less beneficial.

We explored whether higher investment in $R \& D$ moderates the effect of potential social capital on involvement in foreign markets. We found that firms that invest heavily in $R \& D$ are better able to exploit home potential social capital for participation in the international markets for goods, but that firms that invest substantially in $R \& D$ and are located in socially rich regions are less prone to being involved in international markets for technology. We argue that these findings can be explained by a complementarity effect, between R\&D investment and potential social capital in the form of social interaction within a region, on the markets for goods. R\&D investment enhances the quality and novelty of a firm's products, and makes links to other local organizations, facilitated by potential social capital, more valuable. We conjecture that the findings for transacting in international markets for technology can be explained by a substitution effect at work between R\&D investment and potential social capital, in the form of social interaction within a region: located in socially rich regions that also invest heavily in $R \& D$ are more likely to use their technologies in-house because they are more likely to have access to the complementary assets needed to commercialize their inventions.

\section{Implications for the Literature}

Our paper extends work in the international business literature showing that firms' social networks matter for their levels of involvement in foreign markets (e.g., Zhou et al., 2007). We contribute the theoretical argument that location in a socially rich region increases the probability that firms will establish links with other organizations in the region that they can learn from and exchange resources with; social capital is easier to create in some locations than others. Extensive social ties among individuals in a region imply that firm managers and employees are more likely to have informal contacts with managers and employees of firms and organizations in the same region. We showed that localized potential social capital is crucial for knowledge and information flows on involvement in foreign markets, and provided empirical support for this claim. 
This paper contributes to the theoretical and empirical literature showing that firms benefit from localized spillovers through local social ties (e.g., Breschi \& Lissoni, 2009; Ceci \& Iubatti, 2012; Cooke et al., 2005; Eapen, 2012; Owen-Smith \& Powell, 2004; Porter, 2000; Saxenian, 1994). Although some studies warn about the possibility and report anecdotal evidence of negative effects (e.g., Porter, 2000: 24), to our knowledge no research has demonstrated these effects using a large-scale data set. We show that when the level of potential social capital goes beyond a certain point, for both of the markets under consideration, firms' involvement in foreign markets decreases. Theoretically, we interpret this as implying that a very high level of social ties induces over-reliance of firms on local opportunities. We also contribute to the literature on geographically bounded social capital (e.g., Guiso et al., 2004; Putnam et al., 1993) by extending it to include not only its effects on how firms behave and perform in the domestic region, but also how geographically bounded social capital affects firm behavior in foreign locations. To benefit from their home environments, it is a necessary condition that firms should be able to obtain and exchange relevant information and knowledge within these environments. In this context, we provide a set of theoretical mechanisms that facilitate acquisition and exchange of this information and knowledge, thereby underpinning the functioning of the aggregate concept of geographically bounded social capital.

Our study also contributes to the emerging literature on the internationalization of intangible resources (Knight \& Kim, 2009). Previous research has examined firms' commercialization of knowledge (Arora et al., 2001), but has not explored the contingencies that affect trade in international technology markets. We believe the present study provides novelty by demonstrating how the external contingencies of the home region shape firms' involvement in foreign markets in the markets for technology. Our final contribution to the international business literature concerns the impact of firms' internal capabilities and knowledge creation on international activity. In line with the international business literature on involvement in foreign markets through exporting (e.g., Cassiman \& Golovko, 2011), we posit theoretically and corroborate empirically that creation of internal knowledge - in the form of R\&D investment - matters for the level of involvement in foreign markets. We also show that the strength of the effect on involvement in foreign markets depends on the properties of the home region in terms of the level of potential social capital, and the character of the market in question (goods or technology).

\section{Implications for Management}

The findings of this study have some implications for managers. First, it helps to delimit the scope of managerial choice related to the export of goods and technologies. We know that access to resources from other organizations (via networks) is crucial for these activities. However, not only are there fewer resources in some regions (we control for resources in our regressions), but we show that access to them is more difficult in socially poor regions. Initial conditions - in terms of geographical location - to a degree dictate the ability of firms to enter international markets. Managers need to be aware that the ability to build networks can be severely constrained (or stimulated) by the focal firm's location. Assuming that all firms are equally advantaged in relation to the potential for connecting to other firms could lead to bad decisions, especially for firms located in socially poor regions. Second, firms located in regions characterized by very high levels of potential social capital are more likely to experience negative consequences in relation to participation in international markets. This may be more easily remedied than location in a socially poor region, because deliberate actions can be undertaken to forge links with more distant firms.

\section{Limitations of This Study and Avenues for Further Research}

This study has some limitations. The data analyzed are cross-sectional; future research should examine whether the results hold for longitudinal data. In particular, cross-sectional data do not allow us to control for the effects of past achievements. The study focuses on one country. This is a limitation common to most (perhaps all) studies of international exporting of goods and technology. However, we consider Italy to be a suitable setting to analyze the role of regional potential social capital, given that there is considerable (and well-documented) cross-region variation within Italy. This variation is a precondition for this type of analysis. Our hypotheses are general: thus the theoretical mechanisms described are not particular to our empirical setting. For this reason we believe that our results are likely to be generalizable, but this is an empirical issue that we are unable to test in the present setting; it is a task for future research. 
We have argued that firms located in social-capital-rich regions can draw more easily on and exchange information, knowledge and other resources within the region, through the private social ties of their managers and employees. It should be underscored that this is an assumption, and therefore a limitation of the present paper; we have no way of knowing whether the business-relevant ties between individuals in their private spheres have actually been forged by potential social capital as it is measured in this paper.

The findings in this paper suggest other avenues for research. R\&D activities increasingly are collaborative, and therefore require the development and management of relationships with a variety of organizations in different locations - including universities and research centers - and different ways of thinking. Interactions involving different mindsets and different geographical contexts may help to broaden the firm's perspectives. It would be interesting to check and control for the nature and location of R\&D partners in relation to the knowledge properties of the home location. Also, the openness of the innovation network (Laursen \& Salter, 2006) may differ along the internationalization process. Hite and Hesterly (2001) argue that the configuration and nature of networks vary over time. During the first phases, networks are mainly identity based, but later consolidate around more formal relationships.

We also considered regional-level potential social capital. Although prior research suggests that social capital is predominantly geographically constrained (Sorenson \& Audia, 2000), it need not be. For

\section{REFERENCES}

Abrahamson, E., \& Fombrun, C. J. 1994. Macrocultures: Determinants and consequences. Academy of Management Review, 19(4): 728-755.

Almeida, P. 1996. Knowledge sourcing by foreign multinationals: Patent citation analysis in the US semiconductor industry. Strategic Management Journal, 17(Winter Special Issue): 155-165.

Almeida, P., \& Kogut, B. 1999. Localization of knowledge and the mobility of engineers in regional networks. Management Science, 45(7): 905-917.

Andersson, U., Forsgren, M., \& Holm, U. 2002. The strategic impact of external networks: Subsidiary performance and competence development in the multinational corporation. Strategic Management Journal, 23(11): 979-996.

Arora, A., Fosfuri, A., \& Gambardella, A. 2001. Markets for technology: The economics of innovation and corporate strategy. Cambridge, MA: MIT Press.

Asheim, B. T. 1996. Industrial districts as "learning regions": A condition for prosperity. European Planning Studies, 4(4): 379-400

Audretsch, D. B., \& Feldman, M. P. 1996. R\&D spillovers and the geography of innovation and production. American Economic Review, 86(3): 630-640. instance, individuals' social ties and derived social capital can be organizational (see e.g., Leana \& van Buren, 1999) or associated with dimensions such as non-local inter-firm relations or a common university background (alumni association). Combining data on actual social capital linked to dimensions other than geography - and especially actual organizational social capital, with data on geographically bounded potential social capital - could provide new and interesting insights into firms' involvement in foreign markets.

\section{ACKNOWLEDGEMENTS}

The authors gratefully acknowledge comments from Kevin Boudreau, John Cantwell, Dajana D'Andrea, Isabel Fernandez-Mateo, Gerry George, Snejina Michailova, Phanish Puranam, Markus Reitzig, Editor Paul Almeida and three reviewers of this journal, the audiences at London Business School, CERAM Business School, Norwegian School of Economics and Business Administration, the University of Auckland Business School, the Universidad Carlos III de Madrid, the DRUID Conference 2009, and the Academy of Management Conference 2010 on earlier versions of this paper. The authors also thank Cristiano Zazzara and the research department at Capitalia (now Unicredit) for the provision of the firm-level data set used in this paper. The usual caveats apply. K. Laursen acknowledges the financial support from the Danish Council for Independent Research | Social Sciences (Grant 09-068739).

Bartlett, C. A., \& Ghoshal, S. 1989. Managing across borders: The transnational solution. Boston, MA: Harvard Business School Press.

Basile, R. 2001. Export behaviour of Italian manufacturing firms over the nineties: The role of innovation. Research Policy, 30(8): 1185-1201.

Baum, J. A. C., \& Haveman, H. A. 1997. Love thy neighbor? Differentiation and agglomeration in the Manhattan hotel industry, 1898-1990. Administrative Science Quarterly, 42(2): 304-338.

Belsey, D. A., Kuh, E., \& Welsch, R. E. 1980. Regression diagnostics: Identifying influential data and sources of collinearity. New York: John Wiley \& Sons.

Beugelsdijk, S., \& Schaik, T. v. 2005. Differences in social capital between 54 western European regions. Regional Studies, 39(8): 1053-1064.

Bonaccorsi, A. 1992. On the relationship between firm size and export intensity. Journal of International Business Studies, 23(4): 605-635.

Boschma, R., \& lammarino, S. 2009. Related variety, trade linkages, and regional growth in Italy. Economic Geography, 85(3): 289-311. 
Breschi, S., \& Lissoni, F. 2009. Mobility of skilled workers and coinvention networks: An anatomy of localized knowledge flows. Journal of Economic Geography, 9(4): 439-468.

Brusco, S. 1982. The Emilian model: Productive decentralisation and social integration. Cambridge Journal of Economics, 6(2): 167-184.

Buckley, P., \& Casson, M. 1976. The future of the multinational enterprise. New York: Holmes \& Meier.

Calise, M. 2000. Il partito personale. Roma-Bari: Laterza.

Calof, J. L. 1994. The relationship between firm size and export behavior revisited. Journal of International Business Studies, 25(2): 367-387.

Cantwell, J. 1989. Technological innovation and multinational corporations. Oxford: Blackwell.

Cantwell, J., \& Janne, O. 1999. Technological globalisation and innovative centres: The role of corporate technological leadership and locational hierarchy. Research Policy, 28(2/3): 119144.

Capello, R., \& Faggian, A. 2005. Collective learning and relational capital in local innovation processes. Regional Studies, 39(1): 75-87.

Capitalia. 2006. Indagine sulle imprese Italiane: Rapporto sul sistema produttivo e sulla politica industriale. Rome: Capitalia.

Cassiman, B., \& Golovko, E. 2011. Innovation and internationalization through exports. Journal of International Business Studies, 42(1): 56-75.

Ceci, F., \& lubatti, D. 2012. Personal relationships and innovation diffusion in SME networks: A content analysis approach. Research Policy, 41(3): 565-579.

Chen, S. 2005. Extending internalization theory: A new perspective on international technology transfer and its generalization. Journal of International Business Studies, 36(2): 231-245.

Chesbrough, H. 2003. Open innovation. Cambridge, MA: Harvard University Press.

Cohen, I., \& Cohen, P. 1983. Applied multiple regression/ correlation analysis for the behavioral sciences, (2nd edn) Hillsdale, NJ: Erlbaum.

Cohen, W. M., \& Levinthal, D. A. 1990. Absorptive capacity: A new perspective of learning and innovation. Administrative Science Quarterly, 35(1): 128-152.

Coleman, J. 1988. Social capital in the creation of human capital. American lournal of Sociology, 94(Supplement): S95-S120.

Coleman, J. 1990. Social capital. Cambridge, MA: Harvard University Press.

Contractor, F. J. 1981. International technology licensing: Compensation, costs and negotiation. Lexington, MA: Lexington Books.

Cooke, P., Clifton, N., \& Oleaga, M. 2005. Social capital, firm embeddedness and regional development. Regional Studies, 39(8): 1065-1077.

Coviello, N., \& Munro, H. 1997. Network relationships and the internationalisation process of small software firms. International Business Review, 6(4): 361-386.

Davidson, W. H., \& McFetridge, D. G. 1985. Key characteristics in the choice of international technology transfer mode. Journal of International Business Studies, 16(2): 5-21.

Della Porta, D. 2004. Political parties and corruption: Ten hypotheses on five vicious circles. Crimes, Law and Social Change, 42(1): 35-60.

Dunning, I. H. 1977. Trade, location of economic activity and the MNE: A search for an eclectic approach. In B. Ohlin, P.O. Hesselborn, \& P.M. Wijkman (Eds), The international allocation of economic activity. New York: Holmes \& Meier, pp 395-418.

Eapen, A. 2012. Social structure and technology spillovers from foreign to domestic firms. Journal of International Business Studies, 43(3): 244-263.

Ellis, P. 2000. Social ties and foreign market entry. Journal of International Business Studies, 31(3): 443-469.

Feldman, M. P. 1994. Knowledge complementarity and innovation. Small Business Economics, 6(5): 363-372.
Fernández, Z., \& Nieto, M. J. 2006. Impact of ownership on the international involvement of SMEs. Journal of International Business Studies, 37(3): 340-351.

Flores, R. G., \& Aguilera, R. V. 2007. Globalization and location choice: An analysis of US multinational firms in 1980 and 2000. Journal of International Business Studies, 38(7): 1187-1187.

Florida, R., Mellander, C., \& Stolarick, K. 2008. Inside the black box of regional development, human capital, the creative class and tolerance. Journal of Economic Geography, 8(5): 615-649.

Fosfuri, A. 2006. The licensing dilemma: Understanding the determinants of the rate of technology licensing. Strategic Management Journal, 27(12): 1141-1158.

Fox, W. 2009. International commercial agreements: A primer on drafting, negotiating, and resolving disputes. Boston, MA: Kluwer Law Intl.

Gambardella, A., Mariani, M., \& Torrisi, S. 2009. How "provincial" is your region? Openness and regional performance in Europe. Regional Studies, 43(7): 935-947.

Gao, G. Y., Murray, J. Y., Kotabe, M., \& Lu, J. 2009. A "strategy tripod" perspective on export behaviors: Evidence from domestic and foreign firms based in an emerging economy. Journal of International Business Studies, 41(3): 377-396.

Gertler, M. S. 2003. Tacit knowledge and the economic geography of context, or the undefinable tacitness of being (there). Journal of Economic Geography, 3(1): 75-99.

Glasmeier, A. 1994. Flexible districts, flexible regions? The institutional and cultural limits to districts in an era of globalization and technological paradigm shifts. In A. Amin \& $\mathrm{N}$. Thrift (Eds), Globalization, institutions, and regional development in Europe. Oxford: Oxford University Press, pp 118-146.

Grabher, G. 1993. The weakness of strong ties. The lock-in of regional development in the Ruhr area. In G. Grabher (Ed), The embedded firm. London: Routledge, pp 255-278.

Greenaway, D., \& Kneller, R. 2007. Firm heterogeneity, exporting and foreign direct investment. The Economic Journal, 117(517): 134-161.

Guiso, L., Sapienza, P., \& Zingales, L. 2004. The role of social capital in financial development. American Economic Review, 94(3): 526-556

Guiso, L., Sapienza, P., \& Zingales, L. 2011. Civic capital as the missing link. In J. Benhabib, M.O. Jackson, \& A. Bisin (Eds), Handbook of social economics. San Diego, CA: North-Holland, pp 417-480.

Guler, I., \& Guillén, M. F. 2010. Home country networks and foreign expansion: Evidence from the venture capital industry. Academy of Management Journal, 53(2): 390-410.

Hardin, J. W. 2002. The robust variance estimator for two-stage models. Stata lournal, 2(3): 253-266.

Hauser, C., Tappeiner, G., \& Walde, J. 2007. The learning region: The impact of social capital and weak ties on innovation. Regional Studies, 41(1): 75-88.

Hedlund, G. 1986. The hypermodern MNC: A heterarchy? Human Resource Management, 25(1): 9-35.

Hite, J. M., \& Hesterly, W. S. 2001. The evolution of firm networks: From emergence to early growth of the firm. Strategic Management Journal, 22(3): 275-286.

Hymer, S. H. 1976. The international operations of national firms: A study of direct foreign investment. Cambridge, MA: MIT Press. lammarino, S., \& McCann, P. 2006. The structure and evolution of industrial clusters: Transactions, technology and knowledge spillovers. Research Policy, 35(7): 1018-1036.

Itami, H. 1987. Mobilizing invisible assets. Cambridge, MA: Harvard University Press.

Ito, K., \& Pucik, V. 1993. R\&D spending, domestic competition, and export performance of Japanese manufacturing firms. Strategic Management Journal, 14(1): 61-75.

Jaccard, J., Wan, C. K., \& Turrisi, R. 1990. Interaction effects in multiple regression. Newbury Park, CA: Sage.

Jaffe, A. B., Trajtenberg, M., \& Henderson, R. 1993. Geographic localization of knowledge spillovers as evidenced by patent citations. Quarterly Journal of Economics, 108(3): 577-598. 
Keeble, D., \& Williamson, F. 1999. High-technology clusters, networking and collective learning in Europe. Ashgate: Aldershot.

Knack, S., \& Keefer, P. 1997. Does social capital have an economic payoff? A cross-country investigation. Quarterly Journal of Economics, 112(4): 1251-1288.

Knight, G. \& Cavusgil, S. 2004. Innovation, organizational capabilities, and the born-global firm. Journal of International Business Studies, 35(2): 124-141.

Knight, G. A., \& Kim, D. 2009. International business competence and the contemporary firm. Journal of International Business Studies, 40(2): 255-273.

Laursen, K., \& Salter, A. J. 2006. Open for innovation: The role of openness in explaining innovative performance among UK manufacturing firms. Strategic Management Journal, 27(2): 131-150.

Laursen, K., Masciarelli, F., \& Prencipe, A. 2012. Regions matter: How localized social capital affects innovation and external knowledge use. Organization Science, 23(1): 177-193.

Lazerson, M. H., \& Lorenzoni, G. 1999. The firms that feed industrial districts: A return to the Italian source. Industrial and Corporate Change, 8(2): 235-266.

Leana, C., \& van Buren, H. 1999. Organizational social capital and employment practices. Academy of Management Review, 24(3): 538-555.

Levinthal, D. A., \& March, J. G. 1993. The myopia of learning. Strategic Management Journal, 14(Winter Special Issue): 95-112.

Mandurino, K. 2011. Sprint di Treviso con i macchinari prodotti «su misura». II Sole 24 ORE. Milan.

Masciarelli, F. 2011. The strategic value of social capital: How firms capitalise on social assets. Cheltenham: Edward Elgar Publishing.

McGrath, R. G. 1997. A real options logic for initiating technology positioning investments. Academy of Management Review, 22(4): 974-996.

Nahapiet, J., \& Ghoshal, S. 1998. Social capital, intellectual capital, and the organizational advantage. Academy of Management Review, 23(2): 242-266.

Nunnally, J. C. 1978. Psychometric theory. New York: McGrawHill.

Oviatt, B. M., \& McDougall, P. P. 1994. Toward a theory of international new ventures. Journal of International Business Studies, 25(1): 45-64.

Owen-Smith, J., \& Powell, W. W. 2004. Knowledge networks as channels and conduits: The effects of spillovers in the Boston biotechnology community. Organization Science, 15(1): 5-21.

Papke, L. E., \& Wooldridge, J. M. 1996. Econometric methods for fractional response variables with an application to 401(k) plan participation rates. Journal of Applied Econometrics, 11(6): 619-632.

Patel, P., \& Vega, M. 1999. Patterns of internationalisation of corporate technology: Location vs home country advantages. Research Policy, 28(2-3): 145-155.

Pavitt, K. 1984. Sectoral patterns of technical change: Towards a taxonomy and a theory. Research Policy, 13(6): 343-373.

Phene, A., \& Almeida, P. 2008. Innovation in multinational subsidiaries: The role of knowledge assimilation and subsidiary capabilities. Journal of International Business Studies, 39(5): 901-919.

Pisano, G. 1990. The R\&D boundaries of the firm: An empirical analysis. Administrative Science Quarterly, 35(1): 153-176.

Podsakoff, P. M., \& Organ, D. W. 1986. Self-reports in organizational research: Problems and prospects. Journal of Management, 12(4): 531-544.

Porter, M. 1990. The competitive advantage of nations. New York: Free Press.

Porter, M. E. 2000. Location, competition, and economic development: Local clusters in a global economy. Economic Development Quarterly, 14(1): 15-34.

Portes, A. 1998. Social capital: Its origins and applications in modern sociology. Annual Review of Sociology, 24: 1-24.
Portes, A., \& Landolt, P. 1996. The downside of social capital. The American Prospect, 26(May-June): 18-21.

Pouder, R., \& St John, C. H. 1996. Hot spots and blind spots: Geographical clusters of firms and innovation. Academy of Management Review, 21(4): 1192-1225.

Powell, W. W., Koput, K. W., \& Smith-Doerr, L. 1996. Interorganizational collaboration and the locus of innovation: Networks of learning in biotechnology. Administrative Science Quarterly, 41(1): 116-145.

Putnam, R. D. 2000. Bowling alone. New York: Simon \& Schuster. Putnam, R. D., \& Goss, K. A. 2002. Introduction. In R.D. Putnam (Ed), Democracies in flux: 3-20. Oxford: Oxford University Press.

Putnam, R. D., Leonardi, R., \& Nanetti, R. Y. 1993. Making democracy work. Princeton, NJ: Princeton University Press.

Roper, S., Love, J. H., \& Higon, D. A. 2006. The determinants of export performance: Evidence for manufacturing plants in Ireland and Northern Ireland. Scottish Journal of Political Economy, 53(5): 586-615.

Rosenberg, N. 1982. Inside the black box: Technology and economics. Cambridge: Cambridge University Press.

Sabatini, F. 2008. Does social capital improve labour productivity in small and medium enterprises? International Journal of Management and Decision Making, 9(5): 454-480.

Salancik, G. R., \& Pfeffer, J. 1977. An examination of needsatisfaction models of job attitudes. Administrative Science Quarterly, 22(3): 427-456.

Saxenian, A. 1994. Regional advantage: Culture and competition in Silicon Valley and Route 128. Cambridge, MA: Harvard University Press.

Schick, A. G., \& Ponemon, L. A. 1993. The influence of auditors' perceptions of organizational decline on audit risk. Organization Science, 4(1): 92-107.

Shupe, D. R., \& Wolfer, J. A. 1966. Comparative reliability of the dogmatism scale with 2 and 6 scale points. Psychological Reports, 19(1): 284-286.

Sorenson, O., \& Audia, G. 2000. The social structure of entrepreneurial activity: Geographic concentration of footwear production in the United States, 1940-1989. American Journal of Sociology, 106(2): 424-462.

Stuart, T., \& Sorenson, O. 2003. The geography of opportunity: Spatial heterogeneity in founding rates and the performance of biotechnology firms. Research Policy, 32(2): 229-253.

Tappeiner, G., Hauser, C., \& Walde, J. 2008. Regional knowledge spillovers: Fact or artifact? Research Policy, 37(5): 861874.

Teece, D. 1981. The market for know-how and the efficient international transfer of technology. The Annals of the American Academy of Political and Social Science, 458(1): 8196.

Teece, D. J. 1986. Profiting from technological innovation: Implications for integration, collaboration, licensing and public policy. Research Policy, 15(6): 285-305.

Telesio, P. 1979. Technology licensing and multinational enterprises. New York: Praeger Publishers.

Trigilia, C. 1986. Small-firm development and political subcultures in Italy. European Sociological Review, 2(3): 161175.

Trigilia, C. 1991. The paradox of the region: Economic regulation and the representation of interests. International Journal of Human Resource Management, 20(3): 306-327.

Tsai, W., \& Ghoshal, S. 1998. Social capital and value creation: The role of intra-firm networks. Academy of Management Journal, 41(4): 464-476.

Uzzi, B. 1997. Social structure and competition in interfirm networks: The paradox of embeddedness. Administrative Science Quarterly, 42(1): 35-67.

von Hippel, E. 2005. Democratizing innovation. Cambridge, MA: MIT Press.

Wagner, J. 2001. A note on the firm size-export relationship. Small Business Economics, 17(4): 229-237. 
Woolcock, M., \& Narayan, D. 2000. Social capital: Implications for development theory, research, and policy. The World Bank Research Observer, 15(2): 225-249.

Wooldridge, J. M. 2002. Econometric analysis of cross section and panel data. Cambridge, MA: MIT Press.

Yli-Renko, H., Autio, A., \& Tontti, V. 2002. Social capital, knowledge, and the international growth of technology-based new firms. International Business Review, 11(3): 279-304.
Zaheer, S. 1995. Overcoming the liability of foreignness. Academy of Management Journal, 38(2): 341-363.

Zhou, L., Wu, W., \& Luo, X. 2007. Internationalization and the performance of born-global SMEs: The mediating role of social networks. Journal of International Business Studies, 38(4): 673-690.

Zucker, L., Darby, M., \& Brewer, M. 1998. Intellectual capital and the birth of US biotechnology enterprises. American Economic Review, 88(1): 290-306. 


\section{APPENDIX}

Table A1 Description of the variables included in the PCA

\begin{tabular}{ll}
\hline Variable & Description \\
\hline $\begin{array}{l}\text { Participation in cultural } \\
\text { associations }\end{array}$ & $\begin{array}{l}\text { People aged } 14 \text { and over who have } \\
\text { participated in meetings of cultural } \\
\text { associations and the like at least } \\
\text { once in the } 12 \text { months before the } \\
\text { interview for every } 100 \text { people } \\
\text { within the same area }\end{array}$ \\
$\begin{array}{l}\text { Participation in } \\
\text { voluntary associations }\end{array}$ & $\begin{array}{l}\text { People aged } 14 \text { and over who have } \\
\text { participated in meetings of voluntary } \\
\text { associations at least once in the } 12 \\
\text { months before the interview for every } \\
100 \text { people within the same area }\end{array}$
\end{tabular}

Participation in
non-voluntary
organizations

organizations

\section{Number of voluntary associations} per region

Money given to associations

\section{Meeting friends regularly}

Social meetings

Satisfaction as to relationships with friends
People aged 14 and over who have participated in meetings of a non-voluntary organization at least once in the 12 months before the interview for every 100 people within the same area

Number of voluntary organizations for every 10,000 people

People aged 14 and over who donated money to an association at least once in the 12 months before the interview for every 100 people within the same area

People aged 16 and over meeting friends at least once a week for every 100 people of the same area

People aged 16 and over attending bars, pubs, clubs at least once a week in the 12 months before the interview for every 100 people within the same area

People aged 14 and over who are very satisfied with their relationships with friends

Question Source

In the last 12 months, have you participated in a meeting or activity of a cultural or similar association at least once? (i)Yes; (ii) No

In the last 12 months, have you participated in a meeting or activity of a voluntary association or similar association at least once?

(i)Yes; (ii) No

In the last 12 months, have you participated in a meeting or activity of a non-voluntary association at least once? (i)Yes; (ii) No

Voluntary organizations registered in the regional registries at 31 December 1999

In the last 12 months, have you donated money to an association at least once? (i)Yes; (ii) No

In the last 12 months, how often have you seen friends in your spare time? (i) Every day; (ii) More than once a week; (iii) Once a week;

(iv) Less than four times a months;

(v) A few times a year; (vi) Never;

(vii) I don't have any friends

In the last 12 months, how often have you attended bars, pubs, clubs in your spare time? (i) At least once a week; (ii) At least once a month; (iii) Less frequently;

\section{(iv) Never}

Please consider the last 12 months, Multi-scope analysis are you satisfied with your relationship on families: "Aspects with your friends? (i) Very satisfied; of daily life"

(ii) Quite satisfied; (iii) Not very satisfied; (iv) Not satisfied at all
Multi-scope analysis on families: "Aspects of daily life"

Multi-scope analysis on families: "Aspects of daily life"

Multi-scope analysis on families: "Aspects of daily life"

Voluntary organizations in Italy

Multi-scope analysis on families: "Aspects of daily life"

Multi-scope analysis on families: "Aspects of daily life"

Multi-scope analysis on families: "The leisure activities of citizens" 


\section{ABOUT THE AUTHORS}

Keld Laursen is a Professor of the Economics and Management of Innovation at Copenhagen Business School and a Professor at the Norwegian School of Economics and Business Administration. He earned his doctorate in international economics from Aalborg University. His current research focuses on open and distributed innovation processes, and on organizational practices and innovation outcomes. He is the research director of the Copenhagen Research Unit on Innovation Search and Entrepreneurship (CRUISE). He serves on several editorial boards.

Francesca Masciarelli is Assistant Professor at the University G. d'Annunzio. She received her doctorate from the University of Trento. Her research interests include social capital, strategy and management of innovation and international business, with particular emphasis on the implications of social capital on firms' competitiveness.

Andrea Prencipe is a Professor of Economics and Management of Innovation at LUISS University. He received his doctorate from SPRU (University of Sussex), where he is an Honorary Professor. His research interests include the implications of modular design strategies for the division and coordination of innovative labor; organizational learning in project-based organizations; and the relationships between social capital, innovation, and internationalization processes.

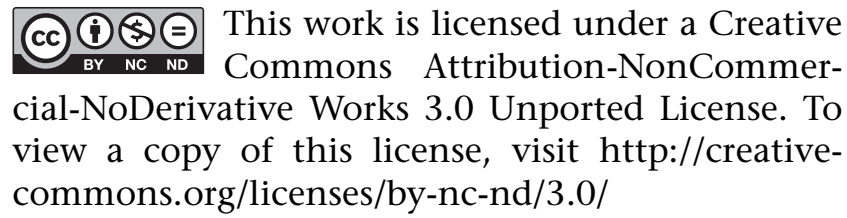

